\title{
Rejuvenating the rewards typology: Qualitative insights into reward preferences
}

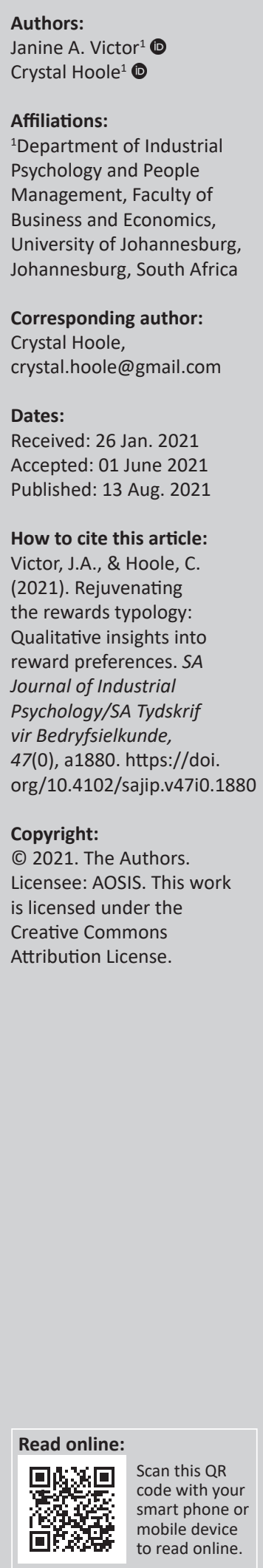

Orientation: In order to drive desirable behaviour, employees need to feel valued. It is, therefore, important to identify which rewards motivate employees and satisfy their needs.

Research purpose: The overarching aims of this study were to explore how South African employees feel rewarded at work and to develop a model depicting how rewards can be categorised.

Motivation for the study: There is a dearth of qualitative research on reward preferences, especially on the psychological façade of this construct.

Research approach/design and method: Using a phenomenological research approach and in-depth interviewing techniques, 47 South African employees participated in focus group sessions. To analyse the data, a deductive and constructionist thematic analysis was employed.

Main findings: The rewards construct is perceived to be multidimensional. Rewards can be categorised into three main categories: (1) extrinsic financial rewards (consisting of the total remuneration package), (2) extrinsic non-financial rewards (inclusive of good relationships, learning and development opportunities, organisational culture, communication, recognition, the physical working environment, feedback and work-life balance) and intrinsic-psychological rewards (encapsulating autonomy, meaningful work, felt competence, task enjoyment and challenging work).

Practical/managerial implications: Outdated reward strategies should be re-evaluated to include all three categories of rewards. This means that there should also be a more in-depth focus on intrinsic-psychological rewards in the workplace.

Contribution/value-add: This study highlighted the importance of using extrinsic (financial and non-financial) as well as intrinsic-psychological rewards to motivate employees and satisfy their needs. The insights gained from this research study can be used by future researchers and practitioners to construct modernised rewards frameworks.

Keywords: reward preferences; extrinsic financial rewards; extrinsic non-financial rewards; intrinsic-psychological rewards; work motivation; job satisfaction; qualitative research.

\section{Introduction}

\section{Orientation}

For many people, work is no longer a choice. People draw on their earnings to uphold basic survival needs, live comfortably, pursue recreational activities and in general, afford characteristics of the modern lifestyle (Cosma \& Gilceava, 2014; Javid \& Chapa, 2014; Pasztor \& Valent, 2016; Yao, Parker, Arrowsmith, \& Carr, 2017; Yousaf, Latif, Aslam, \& Saddiqui, 2014). Although the importance of pay cannot be overstated, the idea that employees merely seek money from what they do is not necessarily true. Whilst financial rewards may be used to satisfy the basic needs of employees as well as attract and retain top talent (Alhmoud \& Rjoub, 2019; Osibanjo, Adeniji, Falola, \& Heirsmac, 2014; Terera \& Ngirande, 2014), research has concluded that alone, it is not a sustainable motivational solution to driving their finest performance (Kulchmanov \& Kaliannan, 2014; Mundhra \& Jacob, 2011) or overall, satisfaction with their jobs (Akafo \& Boateng, 2015; Huang, 2016; Ollar \& Uwakwe, 2020). In fact, financial rewards are only 'part of the parcel' in one's working life and not enough for organisations to harness long-term employee motivation and enthusiasm (Kathombe, Kipchumba, \& Kirui, 2018; Mokhniuk, 2016; Mundhra \& Jacob, 2011; Singh, 2016).

The ability of an organisation to ensure employee satisfaction as well as optimal levels of quality performance largely depends on a mix of motivational factors (Roos \& Van 
Eeden, 2008; Snelgar, Shelton, \& Giesser, 2017). Whilst extrinsic motivation is driven by performing something purely for the attainment of an external reward, intrinsic motivation refers to engaging in a task or activity because it is inherently fulfilling (Legault, 2016). Extrinsic rewards include financial incentives inclusive of pay, benefits and bonuses (Mahaney \& Lederer, 2006; Mansaray-Pearce, Bangura, \& Kanu, 2019; Noor \& Gichinga, 2016). They can also be non-financial such as learning and development (L\&D) opportunities, organisational culture, communication and work-life balance (Armstrong, 2014). On the opposite end of the spectrum, intrinsic rewards, derived from one's experience of work, are psychological in nature and provide employees a sense of 'inner' pleasure (Gartner \& Bellamy, 2010; Jacobs, Renard, \& Snelgar, 2014; Obicci, 2015). Such rewards can include meaningful work, job challenge and work enjoyment (Renard \& Snelgar, 2016).

Rewarding employees in the correct way makes them feel valued and engaged towards their work (Victor \& Hoole, 2017). Motivated employees are more likely to produce high quality work (Amabile, 1993; Sabir, 2017). Research has also suggested that highly driven employees tend to perform better (Chaudhary \& Sharma, 2012), have improved wellbeing (Benedetti, Diefendorff, Gabriel, \& Chandler, 2015), enhanced morale (Ogedegbe \& Bashiru, 2014) and good working relationships with their colleagues (Rožman, Treven, \& Čančer, 2017). Therefore, inadequately providing rewards may hamper positive behavioural outcomes, risking the ability of an organisation to function efficiently and competitively. In fact, demotivated employees may exert poor quality efforts in addition to displaying poor commitment towards their organisation (Amabile, 1993). Such attributes may prove detrimental, especially for organisations whose success relies heavily on the use of human capital. It is, therefore, unsurprising that managers and researchers invest a significant amount of time exploring 'key ingredients' to cultivate a highly driven, strong performing and happy workforce.

Given the above, the inadequate provision of rewards may lead to unfavourable employee behaviour. As a result, not only will employees have sub-par levels of motivation and be less satisfied, but organisations may experience an upsurge of talent resigning in pursuit of employment opportunities which offer them more desirable rewards. Therefore, it is pertinent to determine what employees ultimately want from their jobs.

In addition to the above, few studies have qualitatively explored reward preferences. This means that it is unknown whether employees still perceive and understand reward practices based on traditional classifications and theoretical frameworks. The new world of work has brought many changes affecting almost every aspect of work and will, undoubtedly, also affect what workers value in the workplace (Scott, McMullen, \& Larson, 2017; Willis Towers Watson, 2018). Furthermore, the study of intrinsicpsychological rewards is lacking and remains greatly underexplored within literature (Nujjoo \& Meyer, 2012; Renard \& Snelgar, 2016). The study of such rewards may assist managers and behavioural practitioners in understanding how jobs should be (re)designed to improve satisfaction levels and provide employees with more inherent meaning (Renard \& Snelgar, 2016).

\section{Research purpose and objectives}

The above elucidates that the study and distribution of rewards are vital for effective employee and organisational functioning. However, there remain gaps in literature regarding reward categories and employee preferences thereof. In addition, qualitative insights into rewards are minimal in the current body of knowledge. Thus, this research study served two key purposes. Firstly, to explore how employees feel rewarded in the workplace and secondly, to suggest a model depicting how rewards can be classified. To assist the research process, four research questions were explored:

- Which factors influence how employees feel rewarded at work?

- Which rewards underlie extrinsic financial rewards?

- Which rewards underlie extrinsic non-financial rewards?

- Which rewards underlie intrinsic-psychological rewards?

\section{Literature review}

\section{Extrinsic and intrinsic motivation}

Motivation drives human behaviour (Ryan \& Deci, 2000). Extrinsic motivation refers to partaking in an activity for the attainment of external rewards (Olafsen, Halvari, Forest, \& Deci, 2015) or a precise goal (Legault, 2016). Extrinsic motivation can be tangible such as pay and benefits or intangible such as praise and recognition (Lai, 2011). Intrinsic motivation involves engaging in an activity for personal significance (Olafsen et al., 2015; Shkoler \& Kimura, 2020). It brings about inherent satisfaction and enjoyment (Legault, 2016). This type of motivation is non-instrumental and intangible and can be demonstrated, for example, by employees who engage in jobs or careers because it brings them innate pleasure (Lai, 2011).

\section{Theories of motivation}

Maslow's hierarchy of needs (Maslow, 1943) is one of the oldest and most well-known theories of motivation. He advocates that individuals strive to satisfy five basic and hierarchically arranged psychological needs, ranging from physiological needs as the most basic, to self-actualisation as the highest order of needs. This theory is based on the premise that unsatisfied needs are what primarily motivates individuals, whereas needs which have previously been fulfilled motivate substantially less (Kaur, 2013). Whilst lower-order needs can be satisfied extrinsically through the provision of basic pay, job security and fringe benefits can help to satisfy safety needs. Social needs can be fulfilled through the formation of collaborative workgroups. With regard to self-esteem needs, managers can provide employees 
with formal or informal recognition. The fulfilment of self-actualisation can be satisfied through challenging job tasks or work which inspires creativity and autonomy (Brevis \& Vrba, 2014).

Herzberg's two-factor theory (Herzberg, Mausner, \& Snyderman, 1959) explicates that certain job factors can result in work motivation and satisfaction. Whilst hygiene factors serve to prevent employee unhappiness and dissatisfaction, motivational factors can actively help employees to reach satisfaction (Chu \& Kuo, 2015). Hygiene factors consist of extrinsic characteristics and consist of 'company policy and administration, technical supervision, interpersonal relations with supervisors, interpersonal relations with peers and subordinates, salary, job security, personal life, work conditions and status' (Dartey-Baah \& Amoako, 2011, p. 2). Motivating factors are intrinsic in nature (Ataliç, Can, \& Cantürk, 2016) and include recognition, achievement, growth possibilities, advancement, responsibility and the work itself (Herzberg et al., 1959).

Self-determination theory (SDT) holds that social environments and individual differences influence autonomous motivation (motivation based on willingness, enjoyment, interest and/or values) as well as controlled motivation (motivation based on coercion and obligation). These two types of motivation result in enhanced performance, experience and psychological well-being (Deci \& Ryan, 1985; Ryan \& Deci, 2000). Motivation is categorised as intrinsic, extrinsic and amotivation (Vallerand, 2001). Deci and Ryan (2015) further maintained that human beings have three basic psychological needs (competence, autonomy and relatedness) which, when satisfied, enhances and supports autonomous motivation, workplace effectiveness and psychological health.

The job characteristics model (Hackman \& Oldham, 1971) advocates that job characteristics including (1) skill variety (range of activities and skills required to carry out work), (2) task identity (job includes completing identifiable work from start to finish with visible outcomes), (3) task significance (extent to which a task influences the lives of others), (4) job autonomy (freedom to make decisions in job) and (5) feedback (information provided on the effectiveness of one's performance). When present, these characteristics trigger certain psychological states. When skill variety, task identity and task significance are present, they elicit an experience of meaningfulness (subjective experience and personal significance of work), whereas autonomy elicits responsibility (based on self-judgement) for work outcomes whilst job feedback elicits knowledge (knowing the effectiveness of one's performance) of actual work results (Hackman \& Oldham, 1976; Mount, Ilies, \& Johnson, 2006). Such characteristics and critical psychological states result in valuable workplace outcomes inclusive of job satisfaction, work motivation and effective work performance (Hackman \& Oldham, 1980).

\section{Extrinsic rewards}

Extrinsic rewards are controlled directly or indirectly by an organisation. These rewards encompass financial facets (e.g. Ajmal, Bashir, Abrar, Khan, \& Saqib, 2015; Hafiza, Shah, Jamsheed, \& Zaman, 2011) as well as non-financial and less tangible components (Gkorezis \& Petridou, 2012; Nujjoo \& Meyer, 2012; Özutku, 2012; Wiese \& Coetzee, 2013). Whilst financial rewards are provided directly by the organisation, non-financial rewards include indirect returns. Extrinsic rewards have been found to heighten employee motivation (Khan, Shahid, Nawab, \& Wali, 2013; Kshirsagar \& Waghale, 2014; Kumar, Hossain, \& Nasrin, 2015; Smith, Joubert, \& Karodia, 2015), job performance (Irshad, 2016) and employee satisfaction (e.g. Erbaşı \& Arat, 2012; Haider, Aamir, Hamid, \& Hashim, 2015; Tausif, 2012).

\section{Extrinsic financial rewards}

Extrinsic financial rewards are transactional and consist of pay and benefits (Armstrong, 2010; Katz \& Van Maanen, 1977; Nujjoo \& Meyer, 2012; Thompson, 2002; WorldatWork, 2007). Together, these rewards encompass the total remuneration package (Armstrong \& Murlis, 2009). Research suggests that direct financial returns include two key compensatory-related returns: base pay (e.g. Armstrong, 2010; Chiu, Luk, \& Tang, 2002; Diankenda, 2015; Hoole \& Hotz, 2016; Nazir, Tayyab, Sajid, Ur Rashid, \& Javed, 2012) and contingent or variable pay (e.g. Armstrong, 2010; Diankenda, 2015; Hoole \& Hotz, 2016; WorldatWork, 2007). Base pay is associated with a fixed, market-related and predetermined rate of pay (Lazear, 2000; Snelgar, Renard, \& Venter, 2013) whereas contingent or variable pay remains unfixed and is linked to an employee's performance, length of work and/or competency or skills level (Horváthová, Davidová, \& Bendová, 2012). Rynes, Gerhart and Minette (2004) contended that pay is a powerful motivator. According to Kathombe et al. (2018), pay is the primary reason why people engage in work. This is further supported by Kulchmanov and Kaliannan (2014) who found that pay serves as an important motivator for the purpose of satisfying extrinsic or basic needs.

Indirect financial rewards consist of employee-type benefits (e.g. Armstrong, 2010; Arnolds \& Venter, 2007; Chen \& Indartono, 2008; Kimunge \& Were, 2014). Fringe benefits are discretionary returns provided by organisations (Klonoski, 2016; Koskey \& Sakataka, 2015). Examples include healthrelated benefits and retirement or pension benefits (Armstrong, 2010; WorldatWork, 2007). Such benefits are increasingly being used to improve employee performance (Prasetio, Luturlean, \& Agathanisa, 2019), well-being (through the provision of healthcare benefits) and commitment to organisations (Bender, Contacos-Sawyer \& Thomas, 2013; Klonoski, 2016).

\section{Extrinsic non-financial rewards}

Extrinsic non-financial rewards are considered intangible and relational (Armstrong, 2010; Joshi, 2016). These rewards can only be controlled by the organisation through the 
influence of the working context itself. According to Joshi (2016), these rewards positively contribute towards satisfying intellectual demands to enable the enhanced use of one's talent and strengthen supportive relations. As supported in the literature, non-financial rewards (or relational rewards) are inclusive of L\&D opportunities as well as the working environment (Armstrong \& Stephens, 2005; Koskey \& Sakataka, 2015; Mottaz, 1985).

Learning and development opportunities are prospective circumstances provided to employees for the purpose of developing and enhancing knowledge, competencies and skillsets (Armstrong, 2014). The provision of such opportunities can lead to experiences which are satisfying and rewarding for employees (Joshi, 2016). A working environment can be conceptualised as the surroundings in which an employee engages in the employment relationship (Ushie, Agba, \& Okorie, 2015). The Towers Perrin total rewards strategy advocates that the working environment consists of (1) organisational culture: the manner in which behaviour is enacted through shared organisational values, attitudes and expectations, (2) leadership: the way in which leaders inspire others, (3) communication: the manner in which information is conveyed, received and understood, (4) involvement: the degree of inclusion and participation in fulfilling organisational goals, (5) work-life balance: the provision of flexible working practices and (6) non-financial recognition: appraisal for work well performed (Armstrong, 2014). Perry and Porter (1982) advocated that aspects within the working environment include relationships with peers and supervisors, reward systems, the physical working environment and organisational climate.

\section{Intrinsic-psychological rewards}

Intrinsic rewards entail positive experiences which emanate from the 'inner self' by engaging in the working context (Gartner \& Bellamy, 2010; Obicci, 2015; Thomas, 2009). These rewards are intangible (Jacobs et al., 2014), psychological in nature (Obicci, 2015) and cannot be provided by external sources (Stander \& Van Zyl, 2016). They serve as both motivators and satisfiers to influence, shape and reinforce certain behaviours (Jacobs et al., 2014).

Intrinsic reward theory provides a platform to understand how work can be both motivating and satisfying by engaging in work tasks and content (Renard \& Snelgar, 2016). Intrinsic rewards can be classified into six job and psychologicallyrelated dimensions (including meaningful work, felt responsibility for work outcomes, felt challenge, a sense of competence, task interest and enjoyment and a sense of achievement (Obicci, 2015; Opperman, 2016; Renard \& Snelgar, 2016; Smith et al., 2015).

Meaningful work is a subjective experience of work (De Crom \& Rothmann, 2018; Michaelson, 2019). It involves recognising one's job as worthwhile, fulfilling and which provides one with a sense of purpose (Thomas, 2009). Meaningful work may be considered an intrinsic-psychological reward on the basis that it generates positive feelings (Hackman \& Oldham, 1976) and may serve as a source of job satisfaction (Kamdron, 2005; Steger, Dik, \& Duffy, 2012) and motivation (Scroggins, 2008; Thomas, 2009). Meaningful work has also been positively linked to intrinsic motivation and rewards (Jacobs et al., 2014; Renard \& Snelgar, 2016; Thomas, 2009; Victor \& Hoole, 2017).

Felt responsibility for work outcomes is regarded as a psychological concept (Bateman \& O'Connor, 2016; Fuller, Marler, \& Hester, 2006; Hackman \& Oldham, 1976). It is a concept associated with the degree to which an individual believes that he or she has managed to influence or exert control over the production of work tasks. This construct can elicit positive feelings (Avey, Avolio, Crossley, \& Luthans, 2009; Olckers, 2013). When individuals experience responsibility for the completion of work tasks, they feel that they have made a contribution towards successes and have been able to potentially influence the wider organisation (O'Reilly, 2002). To enhance autonomy and a sense of choice, research has suggested that it is important that organisations redesign jobs which sufficiently allow employees to acquire more responsibility (Marchington \& Wilkinson, 2008). When work tasks enhance one's sense of responsibility, employees experience this as intrinsically and psychologically rewarding (Nujjoo \& Meyer, 2012).

Challenging work includes aspects of a job which are demanding and stimulating (Preenen, Van Vianen, \& De Pater, 2014). Feeling challenged allows employees to exert efforts by drawing on a range of capabilities (Saleem, Mahmood, \& Mahmood, 2010). When tasks are perceived to be challenging (Scasserra, 2008), individuals engage in learning by utilising novel skills and knowledge (Renard \& Snelgar, 2016). Literature suggests that challenging work is rewarding (e.g. Boswell, Olson-Buchanan, \& LePine, 2004; Jacobs et al., 2014; Hafiza et al., 2011; Opperman, 2016; Renard \& Snelgar, 2016; Sarwar \& Abugre, 2013). LutgenSandvik, Riforgiate and Fletcher (2011) found that challenging work often leads to positive-emotional experiences. Such work has also been recognised as an intrinsic reward (Jacobs et al., 2014; Mottaz, 1985; Renard \& Snelgar, 2016; Sarwar \& Abugre, 2013) and as a source of motivation (Herzberg et al., 1959) and satisfaction (Hackman \& Lawler, 1976; Savery, 1989).

A sense of competence as an intrinsic reward has been acknowledged in motivational studies (e.g. Lai, 2011; Ryan \& Deci, 2000; Thomas, 2009; Vallerand \& Reid, 1984). Thomas (2009) defined this concept as internal feelings of pride and satisfaction associated with being able to cope well with tasks, performing at or beyond one's own standards and producing work of worth. This concept is associated with judgements pertaining to one's ability to successfully carry out tasks (Sundström, 2006) as well as to fulfil job demands (Muindi \& K'Obonyo, 2015). Therefore, when individuals are able to effectively carry out work, they feel more enabled and competent in their jobs. In this way, individuals feel more 
energised towards completing a task, which, in turn, results in a more satisfying and fulfilling job-related experience (Riley, 2016).

Task interest and enjoyment are closely related concepts and have been well explored in literature surrounding intrinsic rewards (Jacobs et al., 2014; Kalleberg, 1977; Mottaz, 1985; Renard \& Snelgar, 2016; Westover \& Taylor, 2010). Task interest can be derived from activities which employees perceive as enjoyable or 'fun' to engage in (Crane, 2012). Being interested in tasks prompts one's attention and heightens one's desire to be involved with and explore stimuli more intricately. Enjoyment of work, similarly, evokes passionate involvement with tasks (Buelens \& Poelmans, 2004) and elicits feelings of pleasure (Bredmar, 2013), satisfaction (Crane, 2012), captivation (Malone, 1981) and excitement (Durik \& Harackiewicz, 2007).

A sense of achievement is a positive feeling which an individual experience when he or she has excelled at something. It entails knowing that something was preformed right (Shahzadi, Javed, Pirzada, Nasreen, \& Khanam, 2014) and produced with high quality standards (Damij, Levnajić, Rejec Skrt, \& Suklan, 2015). When individuals experience a sense of achievement, they feel that they have produced high quality work. A sense of achievement has been positively correlated with increased work motivation and job satisfaction (e.g. Damij et al., 2015; Danish \& Usman, 2010; Singh \& Tiwari, 2011). This concept has also been regarded as a dimension underlying intrinsic rewards (Mahaney \& Lederer, 2006; Shahzadi et al., 2014; Thomas, 2009).

\section{Research design}

\section{Research approach and strategy}

The methodological approach was qualitative, explanatory and descriptive. Explanatory research was undertaken to connect ideas under a general concept (Neuman, 1997) whilst a descriptive approach was used to acquire experiential meaning and interpretations from participants. A phenomenological research approach was further employed to understand and describe, with more intricacy, how employees distinguish and perceive workplace rewards.

\section{Entrée and establishing researcher roles}

The researcher sent out a formal email to relevant stakeholders requesting permission to conduct research. The email specified: the research purpose, potential value addition, criteria for participation, procedures to collect data, ethical considerations and contact details of the research team. Participating organisations were given ample opportunity to respond to the research request. Once permission had been obtained, the researcher contacted the relevant personnel to assist with logistical arrangements. The primary researcher was positioned as taking on the role of an 'outsider' (Råheim et al., 2016). The researcher was not seen as occupying a participant role, but rather framed as an enquirer of information and an active listener.

\section{Research participants and sampling methods}

This study sought to gather rich insights through in-depth interviews from South African workers. Purposive and convenience sampling was used to select and recruit participants. The sample criteria were to have at least 1 year of working experience to ensure that they had sufficient experience in receiving rewards. Participants were required to be able to express themselves in the English language. These strategies were chosen to ensure sufficient representation of the general South African working population as well as to enhance external validity.

Representation of the final sample is depicted (Table 1). The sample consisted of 47 participants who were predominantly male (57\%) and had a mean age of 34.85 years. Participants had at least 1 year of working experience. The majority of the sample had between 1 and 5 years of working experience (34\%). With regard to race distribution, the sample comprised primarily of black participants $(53 \%)$ followed by white participants $(34 \%)$. Participants mostly spoke English (38\%) followed by isiXhosa (17\%). In terms of educational qualifications, the majority of participants had tertiary level qualifications consisting of diplomas or certificates, bachelor's degrees and honours degrees (19\%) whilst the remaining sample had a grade 11 or lower level of education (17\%). The majority of the sample was employed in the legal industry followed by the building and construction industry (see Table 3).

TABLE 1: Frequency distribution of participant demographics.

\begin{tabular}{|c|c|c|c|}
\hline Item & Category & Frequency & Percentage $(\%)$ \\
\hline \multirow[t]{2}{*}{ Gender } & Male & 27 & 57 \\
\hline & Female & 20 & 43 \\
\hline \multirow[t]{4}{*}{ Race } & White & 16 & 34 \\
\hline & Black & 25 & 53 \\
\hline & Indian or Asian & 4 & 9 \\
\hline & Coloured & 2 & 4 \\
\hline \multirow[t]{7}{*}{ Home language } & English & 18 & 38 \\
\hline & Afrikaans & 5 & 11 \\
\hline & Sesotho & 2 & 4 \\
\hline & Setswana & 3 & 6 \\
\hline & isizulu & 7 & 15 \\
\hline & isiXhosa & 8 & 17 \\
\hline & Xitsonga & 4 & 9 \\
\hline \multirow[t]{8}{*}{ Educational qualification } & Grade 11 or less & 8 & 17 \\
\hline & Grade 12 & 5 & 11 \\
\hline & Diploma or certificate & 9 & 19 \\
\hline & B.Tech & 2 & 4 \\
\hline & Bachelor's degree & 9 & 19 \\
\hline & Honours degree & 9 & 19 \\
\hline & Master's degree & 4 & 9 \\
\hline & Doctoral degree & 1 & 2 \\
\hline \multirow{4}{*}{$\begin{array}{l}\text { Working experience } \\
\text { (years) }\end{array}$} & $1-5$ & 16 & 34 \\
\hline & $6-10$ & 13 & 28 \\
\hline & $11-20$ & 13 & 28 \\
\hline & $21+$ & 5 & 11 \\
\hline
\end{tabular}




\section{Research setting}

The setting of the study was profit-driven organisations in the Johannesburg area of the Gauteng region. Profit-driven organisations were selected as the study aimed to identify rewards which employees are attracted to from a financial, non-financial and psychological perspective. The focus group sessions were carried out at the offices of participants because of convenience. Focus groups 5 and 6 took place off-site at a private residence. The setting did not seem to hinder participants in sharing their views.

\section{Data collection methods}

Data were collected through conducting focus groups. Each focus group consisted of at least three participants and ranged between $1 \mathrm{~h}$ and $2 \mathrm{~h}$. To elicit meaningful responses and ensure validity of the data, questions were aligned with appropriate theory (Renard \& Snelgar, 2016). To ensure context, structure and adequate regulation of the sessions, open-ended and semi-structured questions were presented in an interview guide. Examples of questions were 'what aspects of your job/manager/organisation make you happy at work?' and 'what aspects of your job/manager/ organisation motivate you to give your utmost best?'.

\section{Data recording}

Focus group sessions were audio-recorded via an electronic device. The purpose of these recordings was to ensure that the researcher did not miss out on any useful information. Hand-written notes were further taken which included content discussed and participatory interactions. Audiorecordings were gathered for verbatim transcription within a week of hosting the sessions.

\section{Strategies employed to ensure data quality and integrity}

Permission to conduct research was granted and approved by the relevant institution's research committee. The researcher explained ethical issues and potential risks associated with participants. This included outlining (1) the purpose and nature of the study, (2) willingness and voluntary participation, (3) opportunity to withdraw at any time, (4) choice to refuse to answer questions without consequence, (5) opportunity to ask questions surrounding involvement, (6) understanding that data collected will be used for research purposes only, (7) no offerings in exchange for participation, (8) the use of audio-recordings, (9) confidentiality, anonymity and disguising of personal identification and (10) the provision of the research teams contact details should any queries arise in the future. Thereafter, written informed consent and request for audiorecordings were required from participants.

\section{Trustworthiness}

The strategies used to ensure trustworthiness of data in this study are outlined (Table 2).
TABLE 2: Strategies employed to ensure trustworthiness of data.

\begin{tabular}{ll}
\hline Strategy & Application and criteria \\
\hline Credibility & $\begin{array}{l}\text { Data triangulation: The researcher made use of multiple sources } \\
\text { of information and compared and contrasted perspectives. } \\
\text { Theoretical triangulation: The researcher revised multiple } \\
\text { theoretical stances. } \\
\text { Member-checking: A summary of information was fed back to } \\
\text { participants to ensure that the researcher had correctly } \\
\text { interpreted and understood their articulations. }\end{array}$ \\
Transferability & $\begin{array}{l}\text { Purposive sampling: Participants selected and recruited were } \\
\text { employees in profit-driven organisations. }\end{array}$ \\
Dependability & $\begin{array}{l}\text { Detailed descriptions of study for replication purposes: Detailed } \\
\text { accounts of how the study was carried out including the research } \\
\text { design, participant information, context and other } \\
\text { methodological considerations were documented. }\end{array}$ \\
Confirmability & $\begin{array}{l}\text { Audit trail: Detailed accounts of the processes and procedures } \\
\text { used to collect, analyse and interpret the data were provided. }\end{array}$ \\
\hline
\end{tabular}

\section{Data analysis}

To analyse the data, a deductive and social constructionist thematic analysis was employed. A thematic analysis was used to assess and explore definitive trends, themes and patterns in the data (Braun \& Clarke, 2006). This method was used to understand the meaning and significance that employees assigned to workplace rewards. This allowed the researcher to further explore which types of rewards underpin the broader categories of rewards. The widely used phases devised by Braun and Clarke (2006) were implemented. In phase one, the researcher began by becoming familiar with the data. This entailed actively reading through the transcribed data and listening to the voice recorded data again to ensure accuracy in transcriptions.

The second phase entailed generating initial codes. A manual process was adopted whereby the researcher acknowledged codes through identifying aspects within the data which appeared interesting and useful. These initial codes were identified to establish meaningful categories which aligned to the research questions (Fielden, Sillence, \& Little, 2011).

The third phase encompassed searching for themes. Previously, identified codes were sorted into broader themes by taking relationships amongst codes, themes and subthemes into consideration. The researcher further refined the data by sorting and placing line-by-line detail under the differing themes. Because of the extensive nature of transcriptions, the search for themes was repeated for second and third time.

The fourth phase included the revision of themes where themes were revised for collection, refinement and/or deletion. Drawing on the recommendations provided by Maguire and Delahunt (2017), this entailed reviewing themes and subthemes to check whether (1) data supported themes (2) themes made sense (3) there was too much, or too little detail included within a theme (4) there were prominent overlaps amongst themes and (5) there were themes which can be separated. This step entailed deleting themes which did not produce coherent patterns in accordance with the broader dataset. 
In the final phase, themes were defined and termed. This involved identifying and articulating what each theme broadly meant whilst explicating similar features amongst subthemes. Thereafter, each theme was given a name. The thematic analysis process ended off with highlighting transcribed and coherent examples which exemplifies each theme.

\section{Reporting style}

An objective approach was adopted in analysing and writing up the research results. Themes and subthemes based on the objective of each research question were developed and used to report the results of the study. This was substantiated by concepts identified in the literature. Verbatim accounts of participant views were provided and any identifying information was hidden by means of referring to focus group sessions (e.g. S1, S2...S6) and participants (e.g. Participant A, B, C).

\section{Ethical considerations}

Ethical clearance was obtained from the research committee of University of Johannesburg, reference number: IPPM2017-162 (D)

\section{Results \\ Composition of focus groups}

Demographic information pertaining to interviewees included in each session was depicted (Table 3).

\section{Research results}

The themes and subthemes are presented (Table 4).

\section{Research question 1: Which factors influence how employees feel rewarded at work?}

'Different types of rewards' depict the multidimensional interpretation of the rewards construct. Participants described this theme through two subthemes: 'financial and non-financial rewards and intrinsic rewards'. With regard to 'financial and non-financial rewards', Participant A (S2) expressed:

'[... T] he reward does not always have to be in monetary value. So, it could be a promotion or just a general appreciation of your presence in the office. It does not have to be a physical reward. It could be an improvement in the relationship with your bosses. So, you can have, in that sense, different types of rewards...'

Participant C (S3) drew on concepts of objectivity and subjectivity to distinguish between the financial orientations of rewards:

'... Objective rewards would be those rewards which can be measured such as financial rewards ... Subjective rewards can be viewed as recognition or praise.'

With regard to intrinsic rewards, participants generally agreed that rewards can be internally felt and experienced. During the sixth focus group session, Participant A (S6) provided an in-depth view:
TABLE 3: Focus group participant composition.

\begin{tabular}{|c|c|c|c|}
\hline $\begin{array}{l}\text { Focus } \\
\text { group } \\
\text { session }\end{array}$ & Participant & Job title & Industry \\
\hline \multirow[t]{5}{*}{1} & A & Receptionist & Building and construction \\
\hline & B & Stores manager & Building and construction \\
\hline & C & Supervisor & Building and construction \\
\hline & $\mathrm{D}$ & Quantity surveyor & Building and construction \\
\hline & $\mathrm{E}$ & Supervisor & Building and construction \\
\hline \multirow[t]{5}{*}{2} & A & Usher messenger & Legal \\
\hline & B & Judges clerk & Legal \\
\hline & $\mathrm{C}$ & Administrative clerk & Legal \\
\hline & $\mathrm{D}$ & General assistant & Legal \\
\hline & $\mathrm{E}$ & Judges clerk & Legal \\
\hline \multirow[t]{3}{*}{3} & A & Researcher & Education \\
\hline & B & Lecturer & Education \\
\hline & C & Lecturer & Education \\
\hline \multirow[t]{3}{*}{4} & A & Motor mechanic & Automotive \\
\hline & B & Salesman & Automotive \\
\hline & $\mathrm{C}$ & General assistant & Automotive \\
\hline \multirow[t]{7}{*}{5} & A & General manager & Building and Construction \\
\hline & B & Business analyst & Real Estate \\
\hline & C & Industrial designer & Engineering \\
\hline & $\mathrm{D}$ & Redeployment consultant & Banking \\
\hline & $E$ & Product manager & Healthcare \\
\hline & $\mathrm{F}$ & Teacher & Education \\
\hline & G & General manager & Governance \\
\hline \multirow[t]{4}{*}{6} & A & Management accountant & Building and construction \\
\hline & B & Art director & Advertising and media \\
\hline & $\mathrm{C}$ & Medical representative & Healthcare \\
\hline & $\mathrm{D}$ & Marketing manager & Healthcare \\
\hline \multirow[t]{5}{*}{7} & A & Painter & Building and construction \\
\hline & B & Painter & Building and construction \\
\hline & $\mathrm{C}$ & Painter & Building and construction \\
\hline & $\mathrm{D}$ & Painter & Building and construction \\
\hline & $E$ & Painter & Building and construction \\
\hline \multirow[t]{4}{*}{8} & A & Office assistant & Education \\
\hline & B & Administrative officer & Education \\
\hline & C & Administrator & Education \\
\hline & $\mathrm{D}$ & Finance manager & Education \\
\hline \multirow[t]{11}{*}{9} & A & Registrar & Legal \\
\hline & B & Registrar & Legal \\
\hline & C & Food services assistant & Legal \\
\hline & $\mathrm{D}$ & Usher messenger & Legal \\
\hline & $\mathrm{E}$ & Registrar & Legal \\
\hline & $\mathrm{F}$ & Judges secretary & Legal \\
\hline & G & Judges secretary & Legal \\
\hline & $\mathrm{H}$ & Judges clerk & Legal \\
\hline & 1 & Registrar & Legal \\
\hline & J & Judges secretary & Legal \\
\hline & $\mathrm{K}$ & Registrar & Legal \\
\hline
\end{tabular}

'For me, feeling rewarded comes from a more personal stance. When you remove yourself from the managerial and appreciation side of things, you are kind of doing things for the personal self ... You have to start with "I" personally. It is an internal feeling rather than completely relying on an external source.'

Participants further acknowledged that intrinsic rewards derive from work itself. Whilst interviewees mentioned that $\mathrm{v}$ job role and associated tasks felt rewarding to them, Participant D's (S7) account sums up this consensus:

'Work itself is a reward to me.' 
TABLE 4: Themes and sub-themes.

\begin{tabular}{|c|c|c|}
\hline $\begin{array}{l}\text { Research } \\
\text { question }\end{array}$ & Theme & Subtheme \\
\hline \multirow[t]{2}{*}{1} & Different types of rewards & Financial and non-financial rewards \\
\hline & & Intrinsic rewards \\
\hline \multirow[t]{2}{*}{2} & The total remuneration package & Pay \\
\hline & & Benefits \\
\hline \multirow[t]{13}{*}{3} & Good relationships & Relationships with colleagues \\
\hline & & Relationships with superiors \\
\hline & Learning and development & Practical working experience \\
\hline & opportunities & $\begin{array}{l}\text { Opportunities for advancement } \\
\text { and growth }\end{array}$ \\
\hline & Organisational culture & Cultural fit \\
\hline & & Felt inclusion \\
\hline & Communication & Smooth liaisons \\
\hline & Recognition & Informal recognition \\
\hline & & Formal recognition \\
\hline & Physical working environment & Job resources \\
\hline & & Working conditions \\
\hline & Feedback & Performance feedback \\
\hline & Work-life balance & Work-home flexibility \\
\hline \multirow[t]{7}{*}{4} & Autonomy & $\begin{array}{l}\text { Freedom to execute work to } \\
\text { one's liking }\end{array}$ \\
\hline & Meaningful work & Task significance \\
\hline & & Task identity \\
\hline & Felt competence & Feeling capable to carry out work \\
\hline & Task enjoyment & Enjoyable work \\
\hline & & Job passion \\
\hline & Challenging work & Job challenge \\
\hline
\end{tabular}

\section{Research question 2: Which rewards underlie extrinsic financial rewards?}

Underpinning the theme: the total remuneration package, two subthemes were formulated: pay and benefits. With regard to base pay, words such as salary, wage or earnings were used to describe this concept. Participants outlined the importance of base pay. Participant B (S4) commented:

'Tick the box about salary being one of the first things ... pay allows you to survive.'

Sentiment was shared with Participant A (S4):

'We work for money. At the end of the day that's the main reason for working. We are not all in a field which would be the ideal or our first choice but, at the end of the month, we need to put a roof over our head and food on the table.'

Contingent pay was considered to encompass additional pay provided to employees for going above and beyond basic expectations. Participants mentioned that incentive bonuses should be offered when putting in extra time and effort into their work and resultantly, exceeding expectations. Participant G (S5):

'If money is what you want then you need to put in a little more effort and go the extra mile and put in the hard hours.'

A preference for contingent pay was further supported during session 8 by Participant A (S8) who highlighted:

'As much as I would like to get an extra day off per week, getting that extra R1000.00 bonus for my hard work would make a difference in my life ....'
With regard to benefits, participants mentioned the importance of medical and pension benefits. For example, Participant C (S1) stated the following:

'Types of medical benefits or pension funds are under scale in this company. We don't have those privileges. I mean, 13th cheques we do have but, not the others.'

\section{Research question 3: Which rewards underlie extrinsic non-financial rewards?}

The first theme encapsulates good relationships. Several participants stated that good relationships with colleagues and superiors carry significance. With regard to the first subtheme, good relationships with colleagues, Participant C (S6) stipulated:

'The only thing that really kept me going in my previous job was the people ... It was the people that made it for me. You got up early in the morning and were excited to talk some nonsense with your work mates. It made it more tolerable.'

Participant B (S3) elucidated that relationships kept her happy by knowing that there were people she could talk to when coming to work whilst Participant A (S5) gave a concrete example:

' $[\ldots B] y$ the end of the year, there are a lot of tears and drama but, the rest of the time we are a close team and if you are struggling with something then there is always someone to talk to. Supportive colleagues are important.'

With regard to the second subtheme, good relationships with superiors, participants alluded to feeling rewarded by having smooth interactions with their superiors. Participant C (S2), for example, specified:

'The person you report into. So, the relationship with your supervisor or line manager. That relationship is important towards contributing towards your happiness in the environment....'

Participant A (S6) agreed:

'Basically, the support from and relationships with your managers and leaders ....'

Learning and development opportunities were formulated as the second theme. The first subtheme, practical working experience, was described by interviewees as the acquisition of practical exposure to one's specific occupation. Participant E (S2) specified:

'For me, finishing my Bachelors of Law (LLB) and seeing it in practice. I feel that it is a reward to finally be in the field that I have always wanted to be in. So, I feel rewarded by seeing my degree in action and seeing that work experience ....'

Another example is provided from Participant E (S9):

'Experience and exposure. I have been in a different organisation but haven't been exposed to much until being here. You actually get down and dirty ... Usually in practice we cut corners but here you know all the procedures. So, it definitely has to do with experience more than anything.'

The second subtheme encapsulated opportunities for advancement and growth. Several participants felt rewarded 
when they were offered opportunities for promotion and advancement. Participant A (S5) mentioned that she felt satisfied by growing. Participant D (S2) also alluded to growth:

'It would be growth because Judges can make a difference where they are. So, I find that you don't have a lot of Judges because you can start at lower ranks and learn so that you can also progress... As a Clerk, you interact with all the tears of the courts including Advocates, Attorneys and Judges ... It pushes you because you can become an Advocate or Attorney, and from there, a Judge. So, the growth aspect of it is a motivating factor. With progression and advancement and promotion comes the remuneration ....'

\section{Participant C (S9) stated:}

'Work must be a place of growth because you can't be in a place where you are not growing. The company must give you those opportunities and tools to grow.'

The word promotion was mentioned on numerous occasions to illustrate that advancement opportunities were rewarding. Participant B (S9) elaborated:

'The biggest reward for me would be to be promoted into a higher position.'

Organisational culture was formulated as the third theme. Two subthemes emerged: cultural fit and felt inclusion. A shared sentiment amongst participants was that fitting into and being able to resonate with the culture of the organisation felt rewarding. For example, Participant A (S5) expressed that his attraction to and satisfaction with a company rest largely on the cultural fit:

'If you fit into that culture and those are the kinds of things you want in life, then obviously you will turn to that culture ... I truly feel that it is about whether my character fits part of the company or not.'

Participant F (S5) supported this stance:

'When the culture is healthy and things are done based on trust, then those are the kinds of people you will attract and that's the kind of company you will have whereas if you want to chase money, chase the next best thing, chase profitability and you put your structures in place to attract those kinds of people then that's the kind of people you are going to get.'

With regard to the latter subtheme, felt inclusion, participants felt that a rewarding job encapsulates feeling part of the organisation. Participant C (S5) provided a thorough elaboration:

'We are a family business and the people that work with us don't want to just worry about money. I think their biggest need, from what I have seen, is that they just want to be part of it. As long as they feel that they are part of the family business and that we include them in it then they are pretty happy.'

The fourth theme, communication, was underpinned by the subtheme smooth liaisons. Participant E (S1) explicated that his supervisory duties entail a mediating component where clear liaisons are essential:

'As a supervisor, you are the mediator between your company, client, and the workers. The client and workers rely on you to give the office a message. The office relies on you to give information on site. So, if things go smoothly, your work comes easy and you don't get too many headaches.'

Participant C (S1) contributed to this stance through explicating that communication is essential in her job to ensure that business runs smoothly and successfully:

'Communication. If I get emails, tenders or requests, I have to communicate this with the supervisors and ensure that they have their daily job duties. This is the message from the client that I need to put out there. I have to communicate this with the workers.'

The fifth theme developed was recognition. Both informal recognition and formal recognition were devised as subthemes. In accordance with informal recognition, participants agreed that being recognised informally by others contributed towards feeling rewarded. An example of this stance was provided for by Participant F (S3):

'With praise, with words of thanks, through conversation. Sometimes someone will come to you and say, "well done" or "thanks for this." That is a reward for whatever I have done."

A similar point of view was shared by Participant I (S9) from session 9:

'Sometimes a simple thank you that you have done a good job. Those words are just so important.'

The second subtheme, formal recognition, depicts the planned efforts by organisational members to recognise employee efforts through official acknowledgements. Participants from session 1 felt rewarded from the attainment of a service reward, that is, receiving something to show for one's experience and work efforts. A direct elaboration of this was provided for by Participant D (S1):

'Some people have been here for more than 10 years. If they go to another company, there is no certificate, there is no proof of experience. Just to confirm, we need something to show that we have been here for so long. Like studying, you get a certificate. Something like a medallion would be nice.'

\section{Participant E (S1) agreed with this stance:}

'... I would want a certificate to take home and hang in my house so that my kids can see that daddy goes to work so early and is working hard.'

The sixth theme encompassed the physical working environment. Two subthemes emerged namely, job resources and working conditions. Job resources were mentioned by participants as the provision of utilities to assist employees in carrying out their job tasks efficiently. Participants noted that through the acquisition of adequate resources, their 
jobs were more satisfying. For example, Participant A (S3) specified:

'[...A]lso just resources. They are important to make my job more enjoyable. Things like computers and the internet. Things which allow me to complete my job. So, working in the education sector, you have your internet and prescribed readings. So, just adequate resources.'

Referral to job resources was also mentioned by construction industry employees. For example, during session 1, Participant A (S1) alluded to the importance of having a phone:

'I think our allowances are very low like phones. We talk to guys on site and the office often and we need to get this improved.'

Working conditions were characterised by participants as having an organised and comfortable place of work. An organised environment was seen to include workspaces with a degree of order. Participant J (S3) stated:

'I like working in a neat and looked after environment. I like a nice working environment where I know that the organisation cares for my working space.'

Participant C (S5) further endorsed the importance of good working conditions:

'... The guys in the warehouse just want a decent working conditions ... They say, "as long as you treat me humanly, pay me decently and give me good working conditions then that's all that I want because it is just a job."'

Feedback was developed as the seventh theme. Performance feedback underpinned this theme. Participant C (S6) articulated that a lack of feedback is unsatisfying:

‘Without feedback, you can't better yourself, which gets really frustrating.'

Participant E (S2) went as far as saying:

'If nobody gave me compliments or feedback, I would not be motivated ....'

The final theme encapsulated work-life balance. Participants endorsed that a rewarding job experience entails having the freedom to allocate time to both work duties and personal responsibilities. Therefore, work-home flexibility was developed as a subtheme. An example of this is taken from Participant C (S6):

'I like that about my job as well. I can get time off if I need to do something and make it up the next day. So, flexibility.'

A more in-depth account of this was mentioned by Participant C (S8):

'I want the flexibility to spend time with my family, myself and friends and do other things such as earn an extra income. So it's also important to have a life outside of work ....'

\section{Research question 4: Which rewards underlie intrinsic- psychological rewards?}

Autonomy captured participant views that a rewarding job allows one to feel responsible for work outcomes.
The following subtheme was developed: freedom to execute work to one's liking. Participant A (S5) provided an account of this:

'... Mine is freedom. I can manage my time as I want to. I can manage the people, operations, marketing and all that with total autonomy.'

A similar view was adopted by Participant B (S6):

'For me, its freedom because my boss lets me do whatever I want. In a good way. I have my own path so long as I get the result. It doesn't matter how I do it.'

The word responsibility was mentioned on numerous occasions. For example, Participant G (S9) stated:

'I think being given responsibility because it shows what you previously did was right.'

Meaningful work emerged as a second theme. Participants discussed how they felt rewarded through their experiences of making a positive impact on the lives of others as well as completing work tasks from beginning to end. Task significance and task identity were accordingly developed as subthemes. Participant C (S5) provided a supporting account of task significance:

'To make a difference in a person's life or adding value to them in some sense. That for me, would be the number one fulfilling or satisfying thing about my job. That is what I love so much about my job and that is why I actually stayed where I am, even though I am not being paid as much as I would like to be.'

Participant C (S5) responded with the following stance:

'I find my satisfaction is through working with kids ... It is just so rewarding when the child is struggling with something specific and you just work on it with them and then, all of a sudden, they improve and it is just so nice to see... Sometimes you get kids who are shy or lack self-confidence and then you just really work with them on it and they improve, which is really great to see.'

In line with task identity, Participant B (S5) mentioned the following:

'[..W] hen you start something and are part of the follow through and the closing of the loop ... So, the inception of it, the whole due diligence of the project, everything, all the paperwork, getting finances in place and what not. When I wasn't part of the follow through ... I was so depressed because I never got to see the product of the whole thing complete and being part of it.'

A more in-depth description of this was provided for from Participant D (S5):

'For me, when I am working on a particular design and struggling a lot and then I crack the solution and the product is perfect and from a manufacturing point of view I am happy with the product and it works. That for me is awesome.'

Felt competence emerged as a third theme. Therefore, feeling capable to carry out work was devised as a subtheme. Participants described this theme as feelings of effectiveness 
when performing and carrying out prescribed work. An elaboration of this is taken from Participant B (S2):

'[... Y] ou have to be able to do the work and you have to feel strongly about what you are doing....'

Participant C (S4) supported this stance through elaborating:

'I know my job and put my skills into practice. I am good at what I do.'

Numerous respondents emphasised that a rewarding job encapsulates work which they enjoy. Therefore, enjoyable work and job passion were developed as subthemes. With regard to enjoyable work, Participant C (S2) elucidated:

'... You might get a reward from the job because you might like it and it interests you.'

Participants further used phrases such as I enjoy my job when referring to what they find most rewarding about their jobs.

Having a passion towards one's work was regarded as liking activities which one performs on the job. The word passion was mentioned by several participants as being significant. Participant B (S2) emphasised:

'If you are passionate about what you do and like what you do, that will evolve into the other relationships. So first, your passion for the work.'

Upon being asked about those motivational aspects, Participant A (S2) mentioned:

'I think it's about passion. If you have passion about something, it might not be paying so much but you love to do that thing. It is about what fulfils you.'

The final theme encapsulates challenging work and depicts participants' view that a rewarding job entails the opportunity to invest a higher level of persistence and effort in their work. A job challenge was formulated as a subtheme. Participant E (S3) mentioned:

'[...W]hat would motivate me is when people set challenging goals or when my supervisor sets challenging goals or when I set a challenging goal for myself.'

\section{Participant C (S3) further noted:}

'Something that is very personal and intrinsic is that I feel rewarded when I challenge myself, irrespective of whether it is assigned to me or not.'

\section{Discussion}

\section{Outline of the results}

The purpose this study was to explore how South African employees feel rewarded at work and to develop a model depicting how rewards can be categorised. In accordance with research question 1, De Gieter et al. (2006) identified three main reward categories consisting of financial, non-financial and psychological rewards, aligning directly with the findings of this study. This confirms that the rewards concept is a multidimensional construct.
Despite conflicting views as to which category is most essential (Arnolds \& Venter, 2007; Erbaş1 \& Arat, 2012), employees can be rewarded directly and/or indirectly through the provision of financial and non-financial rewards (Victor \& Hoole, 2017; Yousaf et al., 2014) as well as intrinsically through the design of their tasks (Meyer \& Kirsten, 2012; Renard \& Snelgar, 2016; Thomas, 2009).

With regard to research question 2, participants frequently alluded to feeling rewarded by pay and benefits. Taken together, total remuneration has been identified in prior literature as a subcategory of a rewards strategy (Armstrong, 2010, 2014; Armstrong \& Brown, 2006; WorldatWork, 2007) and is essentially, the first step in rewarding employee behaviour (Jiang, Xiao, Qi, \& Xiao, 2009). Pay and other forms of remuneration not only serve as workplace motivators (Maslow, 1943; McGuinness, 2009) but can be used to satisfy lower order or existence needs (Alderfer, 1972; Maslow, 1943). Lower order needs are pertinent for survival, thus explaining why employees are almost always attracted to these basic types of rewards first (e.g. Alderfer, 1972; Herzberg et al., 1959; Maslow, 1943). In addition, pay particularly stood out as the most important element of total remuneration amongst participants. Concurring with other studies, pay is the main reason for working (Kathombe et al., 2018) and is a strong motivating factor in the workplace (Kulchmanov \& Kaliannan, 2014; Rynes et al., 2004).

In support of the findings for research question 3, literature has argued that social rewards (such as interpersonal relationships with co-workers and supervisors) are extrinsic in nature (Katz \& Van Maanen, 1977; Mottaz, 1985). Sound, constructive and positive interpersonal relationships are deemed to improve worker motivation and satisfaction (Baloyi, Van Waveren, \& Chan, 2014; Basford \& Offermann, 2012; Perry \& Porter, 1982). Social exchange theory particularly supports that when employees have good relations with their supervisors, they are more likely to feel appreciated and in turn, exert more effort (Eisenberger, Huntington, Hutchison, \& Sowa, 1986). Such relations also enable the employee to feel part of the organisation (Ariani, 2015).

As supported by Armstrong and Stephens (2005), L\&D opportunities underlie a relational and non-financial rewards dimension. The provision of L\&D opportunities is a significant motivator (e.g. Herzberg et al., 1959; McGuinness, 2009; Porter \& Lawler, 1968; Ryan \& Deci, 2000) and source of job satisfaction (Herzberg et al., 1959; Porter \& Lawler, 1968; Singh \& Jain, 2013; Spector, 1997). This finding implies that employees who are provided with practical work experience and developmental opportunities have a greater chance to improve their knowledge base, competencies and skillset, thus, allowing them to progress into higher job roles and essentially, grow within the organisation.

Participants highlighted the importance of organisational culture. Aligning with prior research, Armstrong (2014) explicated that organisational culture forms part of a 
relational and non-financial rewards dimension. Respective findings by Yusof, Munap, Badrillah, Ab Hamid and Khir (2017) as well as Belias and Koustelios (2014) indicated that organisational culture may influence employee motivation and job satisfaction. A plausible explanation for this may be that employees want to feel part of a culture where organisations endorse a high degree of teamwork, trust, encouragement or generally, a focus on people (Rasool, Kiyani, Aslam, Akram, \& Rajput, 2012). By feeling supported or 'part of the family', employees may have a more positive attitude towards their company and work. Once employees adopt a positive attitude, they become more enthused to agree with decisions from managers, expect encouraging results and be more successful and motivated in their tasks (Yousaf et al., 2014).

With regard to communication, participants emphasised the significance of smooth liaisons. Communication as a reward is recognised in prior literature (Armstrong, 2014) and is fundamental in motivating and satisfying employees (Kinicki \& Kreitner, 2006). It has previously been found that open and regular communication from managers greatly improves employee morale (Sirota, Mischkind, \& Meltzer, 2006). Effective communication helps organisational members coordinate activities, achieve goals and make decisions (Mutuku \& Mathooko, 2014). According to Mutuku and Mathooko (2014), communication further allows for the distribution of information needed by employees to successfully perform tasks and strengthen relations as well as provide them with direction.

Recognition has been acknowledged as rewarding to employees (Alderfer, 1972; Armstrong, 2014; Herzberg, 1966; Lai, 2011; Maslow, 1943; McGuinness, 2009; Porter \& Lawler, 1968; Ryan \& Deci, 2000). Recognition creates awareness amongst employees that their work efforts are valued and appreciated (Nyakundi, Karanja, Charles, \& Bisobori, 2012). According to Herzberg (1966), recognition helps to build strong levels of motivation amongst employees. A plausible explanation of this is that employees feel valued when managers provide them with appreciation of their work efforts (Hart, 2011). Formally, this can include an organised effort to reward employees for years of service (Amoatemaa \& Kyeremeh, 2016) or informally, through words of thanks (Silverman, 2004).

A sentiment shared amongst participants was that the working environment is considered as rewarding. When job resources and working conditions are adequate, job satisfaction can be enhanced (Yeh, 2014). Participants, particularly, alluded to the importance of an organised working space. Research has supported that the look and feel of office layout and the design of one's workspace are key factors in job satisfaction (El-Zeiny, 2012; Shareef, Husien, \& Omer, 2018)

Participants noted the significance of performance feedback as a reward. As per Hackman and Oldham's (1976) job characteristics theory, feedback is identified as an antecedent of both employee motivation and satisfaction. Knowledge of outcomes is derived from receiving job feedback. When employees are aware of how effective they are or progressing in their jobs, they will have more knowledge pertaining to how their performance impacts outcomes and in turn, what they need to do (and if so) to boost productivity. Performance feedback has been supported by the work of Baskar and Prakash Rajkumar (2015) as a reward to motivate employee behaviour. In line with this, Marthouret and Sigvardsson (2016) found that positive performance feedback serves as a reward which allows employees to feel good about themselves and their work performance.

The final extrinsic non-financial reward that participates felt rewarding was a work-life balance (developed as the subtheme work-home flexibility). Research suggests that the adequate balance of time spent at work and in one's personal life is significantly rewarding (Armstrong, 2014; WorldatWork, 2010). Solanki (2013) found that work-home flexibility leads to greater levels of job satisfaction and motivation. This provides employees with the freedom and discretion in deciding when, where and how to work (Atkinson \& Hall, 2011). It allows employees to maintain their work-life balance (Prowse \& Prowse, 2015) and contributes towards employee happiness (Kiran \& Khurram, 2018).

In accordance with research question 4, the first intrinsicpsychological work-related aspect which participants found rewarding was autonomy. This type of reward is supported in Hackman and Oldham's (1976) job characteristics model. When autonomy is present, the critical psychological state, responsibility, will arise and in turn, boost motivation and job satisfaction. When employees are entrusted with autonomy, they experience a state of felt responsibility. To elicit this state, employees will feel that their job delivers substantial freedom, the opportunity to feel independent and have the choice in scheduling when to carry out work as well as the procedures to do so. In further support of these findings, a sense of responsibility has been found to be significantly rewarding (e.g. Alderfer, 1972; Dugguh \& Ayaga, 2014; Hackman \& Oldham, 1976; Herzberg et al., 1959; Mahaney \& Lederer, 2006; Maslow, 1943; McClelland \& Winter, 1969; Mottaz, 1985; Opperman, 2016; Porter \& Lawler, 1968; Ryan \& Deci, 2000; Syptak, Marsland, \& Ulmer, 1999).

Meaningful work has been extensively researched and concluded to be rewarding to employees in the workplace (e.g. Jacobs et al., 2014; McGuinness, 2009; Obicci, 2015; Opperman, 2016; Park, Park, \& Peterson, 2010; Renard \& Snelgar, 2016; Smith et al., 2015; Thomas, 2009). In this study, participants provided accounts of how task significance and task identity served as being internally rewarding. Concurring with Hackman and Oldham's (1976) job characteristics model, meaningful work is experienced when task significance and task identity are felt by employees. When workers experience their work to be meaningful, motivation and satisfaction can be enhanced. 
Felt competence by feeling capable in carrying out work was recognised as a reward. Feeling competent in performing work has been identified as an intrinsic motivator and reward (e.g. Deci \& Ryan, 1985; Renard \& Snelgar, 2016; Thomas, 2009; Vallerand \& Reid, 1984). When individuals are able to effectively carry out work, they feel more able to successfully complete their tasks. Basic psychological need satisfaction in SDT (Ryan \& Deci, 2000) further supports this view. Satisfying the need for competence is a psychological and cognitive mechanism for enhancing one's motivation as well as satisfaction within a particular environment. According to Ryan and Deci (2000), not only does motivation drive certain behaviours but allows individuals to acquire a sense of fulfilment, which is associated with an internally rewarding experience (Painter, 2011).

Task enjoyment (e.g. Jacobs et al., 2014; Renard \& Snelgar, 2016; Westover \& Taylor, 2010) and challenging work (e.g. Jacobs et al., 2014; Hafiza et al., 2011; Opperman, 2016; Renard \& Snelgar, 2016; Ryan \& Deci, 2000; Sarwar \& Abugre, 2013), as reward concepts, have been extensively supported in literature. These themes are supported by SDT (Ryan \& Deci, 2000) which holds that intrinsically motivated individuals will engage in a task because it is internally satisfying. According to Ryan and Deci (2000), intrinsic motivation is driven by tasks which are fun, interesting or challenging. What is more, whilst the enjoyment of work fuels a passionate involvement with tasks (Buelens \& Poelmans, 2004), individuals who seek challenging work are more inclined to be self-determined (Deci, 1971). Furthermore, challenging work is supported in the two-factor theory, which serves as a motivator. When persons feel challenged in their work, they feel more motivated and report higher levels of satisfaction (Herzberg, 1966). Dartey-Baah and Amoako (2011) found that employees were motivated by and more attracted to jobs which were more challenging.

Given all of the above, it is evident that employees seek a variety of rewards. Whilst extrinsic rewards can be controlled by members of an organisation, intrinsicpsychological rewards are derived directly from one's work. Based on the aforementioned, a rewards model which outlines a holistic approach to rewarding employee behaviour was suggested (Figure 1).

\section{Practical implications}

The results of this study reveal a few practical implications for behavioural practitioners in future practice. A holistic philosophy to rewarding employees is imperative to boost work motivation and job satisfaction. Organisations should reward employees using different types of rewards. When drawing on extrinsic financial rewards, managers should note that base pay is considered a key workplace reward. This means that companies need to ensure that employees regularly get paid for the work that they do. Managers should consider offering other financial rewards such as bonuses and benefits to their employees. When implementing non-financial rewards, there are two imperative façades that

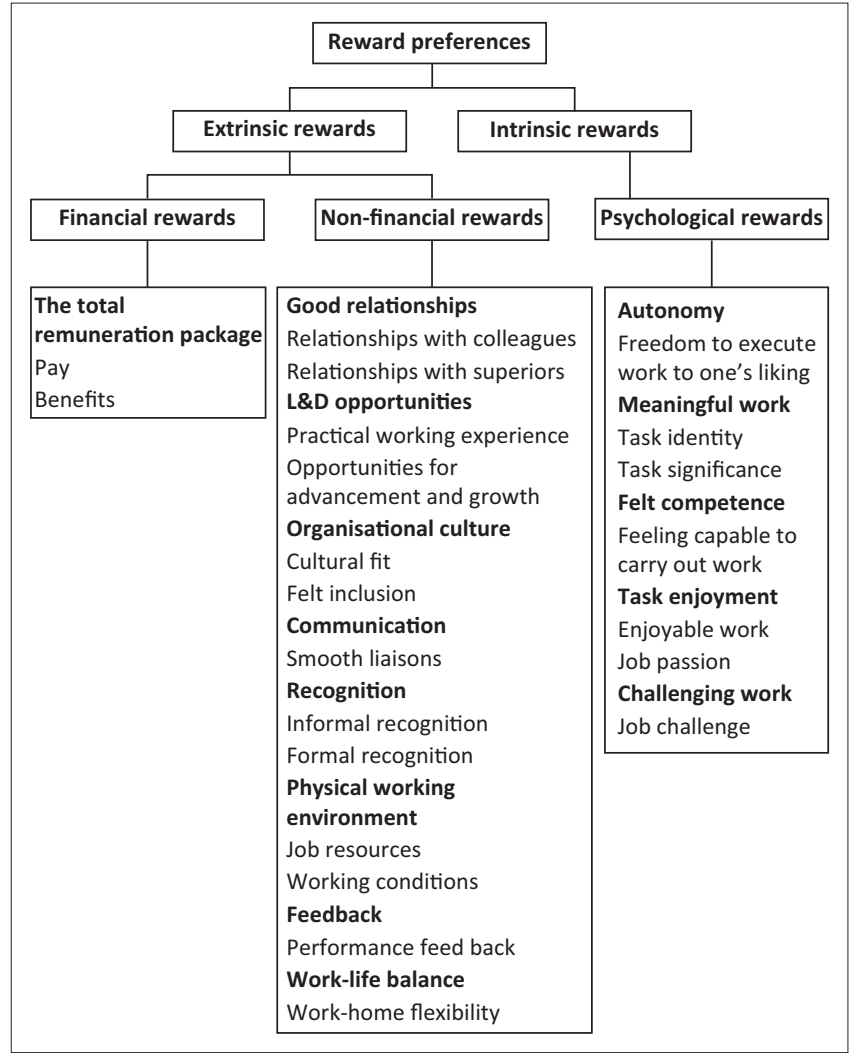

L\&D, learning and development.

FIGURE 1: A clean editable figure was provided in the word document for processing, please check and provide for neat display and clarity in reading as per style guide.

managers need to consider: extrinsic non-financial rewards and intrinsic-psychological rewards. In accordance with the extrinsic non-financial rewards, managers should support, promote and encourage good relationships between employees and their supervisors as well as with their colleagues. The provision of L\&D opportunities, performance feedback and work-life balance should further be nurtured and endorsed. Organisations should ensure that they regularly communicate their core values to employees whilst maintaining transparency to sustain a good organisational culture. Managers should furthermore ensure that employees are able to freely interact with people and information in the workplace. When communication channels are well established within an organisation, interactions and the transfer of information will be uninterrupted and encompass a smooth process. Another way in which managers can ensure that employees feel rewarded is by ensuring that the physical working environment is equipped with adequate resources and good working conditions. It is further evident that managers should acknowledge the efforts of employees informally through conversation (i.e. 'well done') or formally through various types of awards.

With regard to intrinsic-psychological rewards, it was found that employees feel rewarded by the way in which their work tasks are designed. Managers should put their trust in employees to exert autonomy and allow them to execute work tasks according to their liking. To aid in heightening task significance, managers should ensure that employees 
frequently interact with their co-workers, supervisors and those outside the organisation (such as clients and customers) to gain feedback as to how their work impacts others within and outside the organisation (Grant, 2008). To increase one's task identity, managers should broaden and enlarge jobs so that employees are able to see the whole product or identifiable outcome of their work (Lunenburg, 2011). When task significance and identity are heightened, employees should experience their work to be more meaningful.

Another way in which managers could aid the ability of employees to experience their work as intrinsically rewarding is by aiding their felt competence. To boost confidence in their abilities, managers should further support employees' need for autonomy (Baard, Deci, \& Ryan, 2004). This should involve actively entrusting them with freedom and choice as well as allowing them to take initiative in their work (Deci, Eghrari, Patrick, \& Leone, 1994). In line with making jobs more enjoyable, challenging or interesting, it has been suggested to raise manager expectations and, in this way, stretch an employee (Berlew \& Hall, 1966). This means that managers could focus on increasing their expectations of work by encouraging employees to 'go the extra mile' or by being more creative or innovative (Kanter, 1988).

\section{Research limitations and recommendations}

It was not possible to capture the entirety of participants views pertaining to rewards which they desire. This may be attributed to the data collection phase where focus group sessions were restricted to a maximum of $2 \mathrm{~h}$. Thus, probing and exploring additional insights proved challenging. Future researchers should carry out a similar study to confirm the results of this study in addition to identifying additional rewards which underlie the different rewards categories as acknowledged in this study. It is further recommended that a larger sample size be acquired in addition to recruiting participants from other industries and sectors. This study has revealed how employees feel rewarded in the workplace and suggested a new rewards model. Future qualitative studies along this path should identify how perceptions across the different generational cohorts differ. In addition, it is recommended that future qualitative studies explore the relationship between such reward preferences and other behavioural variables such as long-term work satisfaction, commitment and job performance.

\section{Conclusion}

This study highlighted that the concept of reward preferences is a comprehensive topic within the behavioural sciences field. It is indisputable that different types of rewards play an integral role in motivating and satisfying employees. The offering of specific rewards provides crucial reasons as to why employees enter into and remain within the employment relationship. However, the problem with pre-existing reward preference theory is that it is unknown if traditional strategies and practices are still applicable to the modern-day workforce. Given this, it was important to determine what employees ultimately want from their work for organisations to offer rewards which are highly valued. This study supported previous literature findings and clarified that a holistic philosophy to rewarding employees is imperative to boost employee motivation and job satisfaction.

\section{Acknowledgements}

The study was conducted by J.V. as part of her PhD in Industrial Psychology at the University of Johannesburg in 2020 .

\section{Competing interests}

The authors declare that they have no financial or personal relationships that may have inappropriately influenced them in writing this article.

\section{Authors' contributions}

C.H. was J.V.'s supervisor and edited the work for publication. Both authors contributed significantly to the conceptualisation and review of the study.

\section{Funding information}

This research received no specific grant from any funding agency in the public, commercial or not-for-profit sectors.

\section{Data availability}

The data that support the findings of this study are available from the corresponding author, C.H., upon reasonable request.

\section{Disclaimer}

The views and opinions expressed in the article are those of the authors and do not represent the views of any affiliated institution.

\section{References}

Ajmal, A., Bashir, M., Abrar, M., Khan, M.M., \& Saqib, S. (2015). The effects of intrinsic and extrinsic rewards on employee attitudes: Mediating role of perceived organizational support. Journal of Service Science and Management, 8(4), 461 https://doi.org/10.4236/jssm.2015.84047

Akafo, V., \& Boateng, P.A. (2015). Impact of reward and recognition on job satisfaction and motivation. European Journal of Business and Management, $7(24), 112-124$

Alderfer, C. (1972). Existence, relatedness, \& growth. Free Press, New York: Free Press.

Alhmoud, A., \& Rjoub, H. (2019). Total rewards and employee retention in a Middle Eastern context. SAGE Open, 9(2), 1-13. https://doi.org/10.117 7\%2F2158244019840118

Amabile, T.M. (1993). Motivational synergy: Toward new conceptualizations of intrinsic and extrinsic motivation in the workplace. Human Resource Management Review, 3(3), 185-201. https://doi.org/10.1016/1053-4822(93)90012-S

Amoatemaa, A.S., \& Kyeremeh, D.D. (2016). Making employee recognition a tool for achieving improved performance: Implication for Ghanaian Universities. Journal of Education and Practice, 7(34), 46-52.

Ariani, D.W. (2015). Relationship with supervisor and co-workers, psychological condition and employee engagement in the workplace. Journal of Business and Management, 4(3), 34-47. https://doi.org/10.12735/jbm.v4i3p34

Armstrong, M. (2010). Armstrong's handbook of reward management practice: Improving performance through reward. London, PA: Kogan Page Publishers. 
Armstrong, M. (2014). Armstrong's handbook of performance management. London, PA: Kogan Page.

Armstrong, M., \& Brown, D. (2006). Strategic reward: Making it happen. London, PA: Kogan Page Publishers.

Armstrong, M., \& Murlis, H. (2009). Reward management: A handbook of remuneration: Strategy and practice (5th ed.). London, PA: Kogan Page Limited.

Armstrong, M., \& Stephens, T. (2005). A handbook of employee reward management and practice. London: Kogan Page Publishers.

Arnolds, C.A., \& Venter, D.J.L. (2007). The strategic importance of motivational rewards for lower-level employees in the manufacturing and retailing industries. va Journal

Ataliç, H., Can, A., \& Cantürk, N. (2016). Herzberg's motivation-hygiene theory applied to high school teachers in Turkey. European Journal of Multidisciplinary Studies, 1(4), 90-97. https://doi.org/10.26417/ejms.v1i4.p90-97

Atkinson, C., \& Hall, L. (2011). Flexible working and happiness in the NHS. Employee Relations, 33(2), 88-105. https://doi.org/10.1108/01425451111096659

Avey, J.B., Avolio, B.J., Crossley, C.D., \& Luthans, F. (2009). Psychological ownership Theoretical extensions, measurement and relation to work outcomes. Journal of Organizational Behavior: The International Journal of Industrial, Occupational and Organizational Psychology and Behavior, 30(2), 173-191. https://doi. org/10.1002/job.583

Baard, P.P., Deci, E.L., \& Ryan, R.M. (2004). Intrinsic need satisfaction: A motivational basis of performance and well-being in two work settings ${ }^{1}$. Journal of Applied Social Psychology, 34(10), 2045-2068. https://doi.org/10.1111/j.1559-1816.2004. tb02690.x

Baloyi, S., Van Waveren, C.C., \& Chan, K.Y. (2014). The role of supervisor support in predicting employee job satisfaction from their perception of the performance management system: A test of competing models in engineering environments. South African Journal of Industrial Engineering, 25(1), 85-95. https://doi. org/10.7166/25-1-739

Basford, T.E., \& Offermann, L.R. (2012). Beyond leadership: The impact of coworker relationships on employee motivation and intent to stay. Journal of Management \& Organization, 18(6), 807-817. https://doi.org/10.5172/jmo.2012.18.6.807

Baskar, P., \& Prakash Rajkumar, K.R. (2015). A study on the impact of rewards and recognition on employee motivation. International Journal of Science and Research, 4(11), 1644-1648. https://doi.org/10.21275/v4i11.NOV151549

Bateman, T.S., \& O'Connor, K. (2016). Felt responsibility and climate engagement: Distinguishing adaptation from mitigation. Global environmental change, 41 206-215. https://doi.org/10.1016/j.gloenvcha.2016.11.001

Belias, D., \& Koustelios, A. (2014). Organizational culture and job satisfaction: A review. International Review of Management and Marketing, 4(2), 132.

Bender, M., Contacos-Sawyer, J., \& Thomas, B. (2013). Benefits strategies for attracting and retaining employees. Competition Forum, 11(2), 165-169.

Benedetti, A.A., Diefendorff, J.M., Gabriel, A.S., \& Chandler, M.M. (2015). The effects of intrinsic and extrinsic sources of motivation on well-being depend on time of day: The moderating effects of workday accumulation. Journal of Vocational Behavior, 88, 38-46. https://doi.org/10.1016/j.jvb.2015.02.009

Berlew, D.E., \& Hall, D.T. (1966). The socialization of managers: Effects of expectations on performance. Administrative Science Quarterly, 11(2), 207-223. https://doi. org/10.2307/2391245

Boswell, W.R., Olson-Buchanan, J.B., \& LePine, M.A. (2004). Relations between stress and work outcomes: The role of felt challenge, job control, and psychological strain. Journal of Vocational Behavior, 64(1), 165-181. https://doi.org/10.1016/ strain. Journal of Vocationa
S0001-8791(03)00049-6

Braun, V., \& Clarke, V. (2006). Using thematic analysis in psychology. Qualitative research in Psychology, 3(2), 77-101. https://doi.org/10.1191/1478088706qp063oa

Bredmar, A.C. (2013). Teachers' experiences of enjoyment of work as a subtle atmosphere: An empirical lifeworld phenomenological analysis. Indo-Pacific Journal of Phenomenology, 13(Suppl 1), 1-16. https://doi.org/10.2989/IPJP.2013.13.2.6.1180

Brevis, T., \& Vrba, M. (2014). Contemporary management principles. Cape Town: Juta and Company Ltd.

Buelens, M., \& Poelmans, S.A. (2004). Enriching the Spence and Robbins' typology of workaholism: Demographic, motivational and organizational correlates. Journal of Organizational Change Management, 17(5), 440-458. https://doi. org/10.1108/09534810410554470

Chaudhary, N., \& Sharma, B. (2012). Impact of employee motivation on performance (productivity) in private organization. International Journal of Business Trends and Technology, 2(4), 29-35.

Chen, C.H.V., \& Indartono, S. (2008). Perception of direct and indirect compensations fulfillment on hazardous work environment: The relationship with age, tenure, employee's rank and work status. Journal of Economics \& with age, tenure, employe
Education, 5(1), 37-56.

Chiu, R.K., Luk, V.W.M., \& Tang, T.L.P. (2002). Retaining and motivating employees. Personnel Review, 31(4), 402-431. https://doi.org/10.1108/00483480210430346

Chu, H., \& Kuo, T.Y. (2015). Testing Herzberg's two-factor theory in educational settings in Taiwan. The Journal of Human Resource and Adult Learning, 11(1), 54-65.

Cosma, D., \& Gilceava, S.A. (2014). How important is money as an incentive to motivate employees in higher education sector? Literature review. Annals Economy Series, 2, 116-122.

Crane, M.E. (2012). The effects of task autonomy and task interest on goal-setting behavior and task performance. Doctoral dissertation, Cleveland State University. ETD Archive. Retrieved from https://engagedscholarship.csuohio.edu/ etdarchive/476
Damij, N., Levnajić, Z., Rejec Skrt, V., \& Suklan, J. (2015). What motivates us for work? Intricate web of factors beyond money and prestige. PLoS One, 10(7), e0132641. Intricate web of factors beyond money and prestig
https://doi.org/10.1371/journal.pone.0132641

Danish, R.Q., \& Usman, A. (2010). Impact of reward and recognition on job satisfaction and motivation: An empirical study from Pakistan. International Journal of Business and Management, 5(2), 159. https://doi.org/10.5539/ijbm.v5n2p159

Dartey-Baah, K., \& Amoako, G.K. (2011) Application of Frederick Herzberg's two-factor theory in assessing and understanding employee motivation at work: A Ghanaian perspective. European Journal of Business and Management, 3(9), 1-8.

Deci, E.L. (1971). Effects of externally mediated rewards on intrinsic motivation. Journal of Personality and Social Psychology, 18(1), 105. https://doi.org/10.1037/ h0030644

Deci, E.L., Eghrari, H., Patrick, B.C., \& Leone, D.R. (1994). Facilitating internalization: The self-determination theory perspective. Journal of Personality, 62(1), 119-142. https://doi.org/10.1111/j.1467-6494.1994.tb00797.x

Deci, E.L., \& Ryan, R.M. (1985). Intrinsic motivation and self-determination in human behavior. New York: Plenum.

Deci, E.L., \& Ryan, R.M. (2015). Self-determination theory. International Encyclopedia of the Social and Behavioral Sciences, 486-491. https://doi.org/10.1016/B978-008-097086-8.26036-4

De Crom, N., \& Rothmann, S. (2018). Demands-abilities fit, work beliefs, meaningful work and engagement in nature-based jobs. SA Journal of Industrial Psychology, 44, a1496. https://doi.org/10.4102/sajip.v44i0.1496

De Gieter, S., De Cooman, R., Pepermans, R., Caers, R., Du Bois, C., \& Jegers, M. (2006). Identifying nurses' rewards: A qualitative categorization study in Belgium. Human Resources for Health, 4(1), 15. https://doi.org/10.1186/1478-4491-4-15

Diankenda, E. (2015). The relationship between reward management and recognition on employees' motivation in the workplace. Doctoral dissertation, National College of Ireland. NORMA eResearch @NCI Library. Retrieved from http://norma. ncirl.ie/2041/

Dugguh, S.I., \& Ayaga, D. (2014). Job satisfaction theories: Traceability to employee performance in organizations. Journal of Business and Management 16(5), 11-18. https://doi.org/10.9790/487X-16511118

Durik, A.M., \& Harackiewicz, J.M. (2007). Different strokes for different folks: How individual interest moderates the effects of situational factors on task interest. Journal of Educational Psychology, 99(3), 597. https://doi.org/10.1037/00220663.99.3.597

Eisenberger, R., Huntington, R., Hutchison, S., \& Sowa, D. (1986). Perceived organizational support. Journal of Applied Psychology, 71(3), 500. https://doi. org/10.1037/0021-9010.71.3.500

El-Zeiny, R.M.A. (2012). The interior design of workplace and its impact on employees' performance: A case study of the private sector corporations in Egypt. Procedia-Socia and Behavioral Sciences, 35, 746-756. https://doi.org/10.1016/j.sbspro.2012.02.145

Erbaşı, A., \& Arat, T. (2012). The effect of financial and non-financial incentives on job satisfaction: An examination of food chain premises in Turkey. Internationa Business Research, 5(10), 136. https://doi.org/10.5539/ibr.v5n10p136

Fielden, A., Sillence, E., \& Little, L. (2011). Children's understandings' of obesity, a thematic analysis. International Journal of Qualitative Studies on Health and Wellthematic analysis. International Journal of Qualitative Studies
Being, 6(3), 7170. https://doi.org/10.3402/qhw.v6i3.7170

Fuller, J.B., Marler, L.E., \& Hester, K. (2006). Promoting felt responsibility for constructive change and proactive behavior: Exploring aspects of an elaborated model of work design. Journal of Organizational Behavior: The International Journal of Industrial, Occupational and Organizational Psychology and Behavior, 27(8), 1089-1120. https://doi.org/10.1002/job.408

Gartner, W.B., \& Bellamy, M.G. (2010). Enterprise. Ohio: South-Western Cengage Learning.

Gkorezis, P., \& Petridou, E. (2012). The effect of extrinsic rewards on public and private sector employees' psychological empowerment: A comparative approach. The International Journal of Human Resource Management, 23(17), 3596-3612. https://doi.org/10.1080/09585192.2011.639025

Grant, A.M. (2008). The significance of task significance: Job performance effects, relational mechanisms, and boundary conditions. Journal of Applied Psychology, 93(1), 108. https://doi.org/10.1037/a0017974

Hackman, J.R., \& Lawler, E.E. (1971). Employee reactions to job characteristics. Journa of Applied Psychology, 55(3), 259. https://doi.org/10.1037/h0031152

Hackman, J.R., \& Oldham, G.R. (1976). Motivation through the design of work. Organizational Behavior and Human Performance, 16(2), 250-279. https://doi. org/10.1016/0030-5073(76)90016-7

Hackman, J.R., \& Oldham, G.R. (1980). Work redesign. Massachusetts: Addison Wesley.

Hafiza, N.S., Shah, S.S., Jamsheed, H., \& Zaman, K. (2011). Relationship between rewards and employee's motivation in the non-profit organizations of Pakistan. Business Intelligence Journal, 4(2), 327-334.

Haider, M., Aamir, A., Hamid, A.A., \& Hashim, M. (2015). A literature analysis on the importance of non-financial rewards for employees' job satisfaction. Abasyn Journal of Social Sciences, 8(2), 341-354.

Hart, P. (2011). Benefits of employee recognition in the workplace: Reduced risk raised avenues. EHS Today, 4(2), 49-52.

Herzberg, F. (1966). Work and the nature of man. Cleveland: World Publishing.

Herzberg, F., Mausner, B., \& Snyderman, B. (1959). The motivation to work (2nd ed.). New York: John Wiley.

Hoole, C., \& Hotz, G. (2016). The impact of a total reward system of work engagement. SA Journal of Industrial Psychology, 42(1), 1-14. https://doi.org/10.4102/sajip. v42i1.1317 
Horváthová, P., Davidová, M., \& Bendová, M. (2012). Contingent pay and experience with its use by organizations of the Czech Republic operating in the field of environmental protection. International Journal of Economics and Management environmental protection.
Engineering, 6(4), 522-526.

Huang, Y. (2016). Monetary rewards and job satisfaction: A comparison between the United States and China. Journal of Management Research, 8(3), 1-14. https:// doi.org/10.5296/jmr.v8i3.9388

Irshad, A. (2016). Impact of extrinsic rewards on employees' performance. Journal of Global Economics, 4(3), 1-4. https://doi.org/10.4172/2375-4389.1000203

Jacobs, S., Renard, M., \& Snelgar, R.J. (2014). Intrinsic rewards and work engagement in the South African retail industry. SA Journal of Industrial Psychology, 40(2), 1-13. https://doi.org/10.4102/sajip.v40i2.1195

Javid, S., \& Chapa, A. (2014). When money is not a motivating force in the work place. Global Journal of Human-Social Science Research, 14(3), 1-5.

Jiang, Z., Xiao, Q., Qi, H., \& Xiao, L. (2009). Total reward strategy: A human resources management strategy going with the trend of the times. International Journal of Business and Management, 4(11), 177-183. https://doi.org/10.5539/ijbm.v4n11p177

Joshi, P. (2016). Relational rewards: Creating a fulfilling workplace environment. International Journal of Engineering and Management Research, 6(4), 1-5.

Kalleberg, A.L. (1977). Work values and job rewards: A theory of job satisfaction American Sociological Review, 42(1), 124-143. https://doi.org/10.2307/2117735

Kamdron, T. (2005). Work motivation and job satisfaction of Estonian higher officials International Journal of Public Administration, 28(13-14), 1211-1240. https:// doi.org/10.1080/01900690500241085

Kanter, R.M. (1988). When a thousand flowers bloom: Structural, collective, and social conditions for innovation in organizations. Knowledge Management and Organisational Design, 10, 93-131. https://doi.org/10.1016/B978-0-7506-97491.50010-7

Kathombe, M.W., Kipchumba, S., \& Kirui, K. (2018). Reward management strategies and employee performance in selected universities in Nakuru County, Kenya. Journal of Human Resource Management, 6(3), 95-102. https://doi. org/10.11648/j.jhrm.20180603.12

Katz, R., \& Van Maanen, J. (1977). The loci of work satisfaction: Job, interaction, and policy. Human Relations, 30(5), 469-486. https://doi.org/10.1177/001872677 703000505

Kaur, A. (2013). Maslow's need hierarchy theory: Applications and criticisms. Globa Journal of Management and Business Studies, 3(10), 1061-1064.

Khan, I., Shahid, M., Nawab, S., \& Wali, S.S. (2013). Influence of intrinsic and extrinsic rewards on employee performance: The banking sector of Pakistan. Academic Research International, 4(1), 282.

Kimunge, M.W., \& Were, S. (2014). Effects of total rewards on employee retention: A case study of Kenya Vision 2030 delivery secretariat. Strategic Journal of Business \& Change Management, 1(2), 15.

Kinicki, A., \& Kreitner, R. (2006). Organizational behavior: Key concepts, skills \& best practices. Boston: McGraw-Hill/Irwin

Kiran, M., \& Khurram, S. (2018). Flexitime and employee happiness at workplace: A quantitative study of software houses. Pakistan Journal of Commerce and Social Sciences, 12(3), 1008-1024.

Klonoski, R. (2016). Defining employee benefits: A managerial perspective International Journal of Human Resource Studies, 6(2), 52-72. https://doi. org/10.5296/ijhrs.v6i2.9314

Koskey, A.K., \& Sakataka, W. (2015). Effect of reward on employee engagement and commitment at Rift Valley Bottlers Company. International Academic Journal of Human Resource and Business Administration, 1(5), 36-54.

Kshirsagar, M., \& Waghale, V.Y. (2014). Impact of financial and non-financial rewards on employee motivation. International Research Journal of Management and Commerce, 1(6), 61-74.

Kulchmanov, A., \& Kaliannan, M. (2014). Does money motivate employees? Empirical study of private and public financial sector in Kazakhstan. International Journal of Business and Management, 9(11), 214. https://doi.org/10.5539/ijbm.v9n11p214

Kumar, D., Hossain, M.Z., \& Nasrin, M.S. (2015). Impact of non-financial rewards on employee motivation. Asian Accounting and Auditing Advancement, 5(1), 18-25.

Lai, E.R. (2011). Motivation: A literature review. Research report. Pearson. Retrieved from https://images.pearsonassessments.com/images/tmrs/ Motivation_Review_final.pdf

Lazear, E.P. (2000). Performance pay and productivity. American Economic Review, 90(5), 1346-1361.

Legault, L. (2016). Intrinsic and extrinsic motivation. In V. Zeigler-Hill \& T. Shackelford (Eds.), Encyclopedia of personality and individual differences (pp. 1-4). New York: Springer

Lunenburg, F.C. (2011). Motivating by enriching jobs to make them more interesting and challenging. International Journal of Management, Business, and Administration, 15(1), 1-11.

Lutgen-Sandvik, P., Riforgiate, S., \& Fletcher, C. (2011). Work as a source of positive emotional experiences and the discourses informing positive assessment. Western Journal of Communication, 75(1), 2-27. https://doi.org/10.1080/105703 14.2010.536963

Maguire, M., \& Delahunt, B. (2017). Doing a thematic analysis: A practical, step-bystep guide for learning and teaching scholars. All Ireland Journal of Higher Education, 9(3), 3351-3354.

Mahaney, R.C., \& Lederer, A.L. (2006). The effect of intrinsic and extrinsic rewards for developers on information systems project success. Project Management Journal, 37(4), 42-54. https://doi.org/10.1177/875697280603700405
Malone, T.W. (1981). Toward a theory of intrinsically motivating instruction. Cognitive Science, 5(4), 333-369. https://doi.org/10.1207/s15516709cog0504_2

Mansaray-Pearce, S., Bangura, A., \& Kanu, J.M. (2019). The impact of financial and non-financial rewards on employee motivation: Case study NRA Sierra Leone. International Journal of Research in Business Studies and Management, 6(5), 32-41.

Marchington, M., \& Wilkinson, A. (2008). HRM at work: People management and development (4th ed.). London: Chartered Institute of Personnel \& Development.

Marthouret, E., \& Sigvardsson, S. (2016). The effect of quick feedback on employee motivation and performance: A qualitative study on how to formulate effective feedback. Bachelor's dissertation. Linköping University, Sweden.

Maslow, A.H. (1943). A theory of human motivation. Psychological Review, 50(4), 370-396. https://doi.org/10.1037/h0054346

McClelland, D.C., \& Winter, D.G. (1969). Motivating economic achievement. New York: Free Press.

McGuinness, M. (2009). How to motivate creative people (including yourself). Retrieved from https://www.wishfulthinking.co.uk/2009/01/05/how-tomotivate-creative-people/

Meyer, M., \& Kirsten, M. (2012). Introduction to human resource management. Pretoria: Van Schaik.

Michaelson, C. (2019). A normative meaning of meaningful work. Journal of Business Ethics, 170, 413-428. https://doi.org/10.1007/s10551-019-04389-0

Mokhniuk, A.M. (2016). The impact of monetary rewards on the motivation of employees. Roczniki Ekonomiczne Kujawsko-Pomorskiej Szkoły Wyższej w Bydgoszczy, 9, 336-346.

Mottaz, C.J. (1985). The relative importance of intrinsic and extrinsic rewards as determinants of work satisfaction. The Sociological Quarterly, 26(3), 365-385. https://doi.org/10.1111/j.1533-8525.1985.tb00233.x

Mount, M., Ilies, R., \& Johnson, E. (2006). Relationship of personality traits and counterproductive work behaviors: The mediating effects of job satisfaction. Personnel Psychology, 59(3), 591-622. https://doi.org/10.1111/j.1744-6570. 2006.00048.x

Muindi, F., \& K'Obonyo, P. (2015). Quality of work life, personality, job satisfaction, competence, and job performance: A critical review of literature. European Scientific Journal, 11(26), 223-240.

Mundhra, D.D., \& Jacob, W. (2011). Intrinsic motivators in the Indian manufacturing sector: An empirical study. IUP Journal of Organizational Behavior, 10(2), 1-19.

Mutuku, C.K., \& Mathooko, P. (2014). Effects of organizational communication on employee motivation: A case study of Nokia Siemens Networks Kenya. International Journal of Social Sciences and Project Planning Management, 1(3) 28-62.

Nazir, S., Tayyab, A., Sajid, A., Ur Rashid, H., \& Javed, I. (2012). How online shopping is affecting consumers buying behavior in Pakistan? International Journal of Computer Science Issues, 9(3), 486

Neuman, W.L. (1997) Social research methods qualitative and quantitative approaches (3rd ed.). Boston: Allyn and Bacon.

Noor, A., \& Gichinga, D.L. (2016). Effects of reward strategies on employee performance in remittance companies in Mogadishu, Somalia. ljrdo - Journal of Business Management, 2(9), 50-73.

Nuijoo, A., \& Meyer, I. (2012). The relative importance of different types of rewards for employee motivation and commitment in South Africa. SA Journal of Human Resource Management, 10(2), 1-10. https://doi.org/10.2139/ssrn.2851760

Nyakundi, W.K., Karanja, K., Charles, M., \& Bisobori, W.N. (2012). Enhancing the role of employee recognition towards improving performance: A survey of Keyatta National hospital Kenya. International Journal of Arts and Commerce, 1(7), 108.

Obicci, P.A. (2015). Influence of extrinsic and intrinsic rewards on employee engagement: Empirical study in public sector of Uganda. Management Studies and Economic Systems, 54(2518), 1-12. https://doi.org/10.12816/0018083

Ogedegbe, R.J., \& Bashiru, B. (2014). Fostering employee morale through effective remuneration practices. European Journal of Business and Management, 6(16), $112-115$

Olafsen, A.H., Halvari, H., Forest, J., \& Deci, E.L. (2015). Show them the money? The role of pay, managerial need support, and justice in a self-determination theory model of intrinsic work motivation. Scandinavian Journal of Psychology, 56(4), 447-457. https://doi.org/10.1111/sjop.12211

Olckers, C. (2013). Psychological ownership: Development of an instrument. SA Journal of Industrial Psychology, 39(2), 1-13. https://doi.org/10.4102/sajip. v39i2.1105

Ollar, H.Y., \& Uwakwe, F.O. (2020). Organizational reward system and employee job satisfaction in hotels in Rivers State. African Scholar Journal of African Sustainable Development, 17(2), 373-394.

Opperman, A.G. (2016). Supervisory motivational strategies to improve productivity of construction workers. Doctoral dissertation. Cape Peninsula University of Technology, Cape Town.

O'Reilly, C.E. (2002). The wrong kind of ownership. Across the Board, 39(5), 19-20.

Osibanjo, A.O., Adeniji, A.A., Falola, H.O., \& Heirsmac, P.T. (2014). Compensation packages: A strategic tool for employees' performance and retention. Leonardo Journal of Sciences, (25), 65-84.

Özutku, H. (2012). The influence of intrinsic and extrinsic rewards on employee results: An empirical analysis in Turkish manufacturing industry. Business and Economics Research Journal, 3(3), 29-48. 
Painter, J. (2011). Autonomy, competence, and intrinsic motivation in science education: A self-determination theory perspective. Doctoral thesis, University of education: A self-determination
North Carolina, Columbia, SC.

Park, N., Park, M., \& Peterson, C. (2010). When is the search for meaning related to life satisfaction? Applied Psychology: Health and Well-Being, 2(1), 1-13. https:// doi.org/10.1111/j.1758-0854.2009.01024.x

Pasztor, J., \& Valent, S. (2016). Fringe benefit - Still a motivation? In R.Z. Reicher (Ed.), proceedings of FIKUSZ symposium for young researchers (pp. 127-140). Óbud University, Keleti Faculty of Business and Management. Retrieved from https:// www.researchgate.net/publication/311887839_Fringe_Benefit_-_Still_a_
Motivation

Perry, J.L., \& Porter, L.W. (1982). Factors affecting the context for motivation in public organizations. Academy of Management Review, 7(1), 89-98. https://doi. org/10.2307/257252

Porter, L.W., \& Lawler, E.E. (1968). Managerial attitudes and performance. Homewood, IL: Irwin-Dorsey.

Prasetio, A.P., Luturlean, B.S., \& Agathanisa, C. (2019). Examining employee's compensation satisfaction and work stress in a retail company and its effect to increase employee job satisfaction. International Journal of Human Resource increase employee job satisfaction. International Journal of Hum
Studies, 9(2), 239-265. https://doi.org/10.5296/ijhrs.v9i2.14791

Preenen, P., Van Vianen, A., \& De Pater, I. (2014). Challenging tasks: The role of employees' and supervisors' goal orientations. European Journal of Work and Organizational Psychology, 23(1), 48-61. https://doi.org/10.1080/135943 2X.2012.702420 Prowse, J., \& Prowse, P. (2015). Flexible working and work-life balance: Midwives'
experiences and views. Work, Employment and Society, 29(5), 757-774. https:// doi.org/10.1177/095001701557072

Råheim, M., Magnussen, L.H., Sekse, R.J.T., Lunde, Å., Jacobsen, T., \& Blystad, A. (2016). Researcher-researched relationship in qualitative research: Shifts in positions and researcher vulnerability. International Journal of Qualitative Studies on Health and Well-Being, 11(1), 30996. https://doi.org/10.3402/qhw.v11.30996

Rasool, S., Kiyani, A.A., Aslam, M.J., Akram, M.U., \& Rajput, A.A. (2012). Impact of organizational culture on employee's career salience: An empirical study of banking sector in Islamabad, Pakistan. International Journal of Business and Social Science, 3(7), 299-306.

Renard, M., \& Snelgar, R.J. (2016). How can work be designed to be intrinsically rewarding? Qualitative insights from South African non-profit employees. $S A$ Journal of Industrial Psychology, 42(1), 1-12. https://doi.org/10.4102/sajip. v42i1.1346

Riley, G. (2016). The role of self-determination theory and cognitive evaluation theory in home education. Cogent Education, 3(1), a1163651. https://doi.org/10.1080/2 in home education. Cogent

Roos, W., \& Van Eeden, R. (2008). The relationship between employee motivation, job satisfaction and corporate culture. SA Journal of Industrial Psychology, 34(1), 54-63. https://doi.org/10.1108/BEPAM-12-2017-0117

Rožman, M., Treven, S., \& Čančer, V. (2017). Motivation and satisfaction of employees in the workplace. Business Systems Research Journal, 8(2), 14-25. https://doi. org/10.1515/bsrj-2017-0013

Ryan, R.M., \& Deci, E.L. (2000). Intrinsic and extrinsic motivations: Classic definitions and new directions. Contemporary Educational Psychology, 25(1), 54-67. https:// doi.org/10.1006/ceps.1999.1020

Rynes, S.L., Gerhart, B., \& Minette, K.A. (2004). The importance of pay in employee motivation: Discrepancies between what people say and what they do. Huma Resource Management, 43(4), 381-394. https://doi.org/10.1002/hrm.20031

Sabir, A. (2017). Motivation: Outstanding way to promote productivity in employees. American Journal of Management Science and Engineering, 2(3), 35-40. https:// American Journal of Management Science
doi.org/10.11648/j.ajmse.20170203.11

Saleem, R., Mahmood, A., \& Mahmood, A. (2010). Effect of work motivation on job satisfaction in mobile telecommunication service organizations of Pakistan International journal of Business and Management, 5(11), 213. https://doi. org/10.5539/ijbm.v5n11p213

Sarwar, S., \& Abugre, J. (2013). The influence of rewards and job satisfaction on employees in the service industry. The Business \& Management Review, 3(2), 22.

Savery, L.K. (1989). Job satisfaction and nurses. Journal of Managerial Psychology, 4(5), 11-16. https://doi.org/10.1108/EUM0000000001727

Scasserra, D. (2008). The influence of perceived task difficulty on task performance. Doctoral dissertation. Rowan Digital Works. Retrieved from https://rdw.rowan. edu/etd/756/

Scott, D., McMullen, T., \& Larson, E. (2017). The future of work and rewards: Forward thinking from the C-Suite and total rewards leaders. WorldatWork Journal, 26(1), thinkin 24.

Scroggins, W.A. (2008). Antecedents and outcomes of experienced meaningful work: A person-job fit perspective. The Journal of Business Inquiry, 7(1), 68-78.

Shahzadi, I., Javed, A., Pirzada, S.S., Nasreen, S., \& Khanam, F. (2014). Impact of employee motivation on employee performance. European Journal of Business and Management, 6(23), 159-166.

Shareef, V.A., Husien, H.A., \& Omer, S.K. (2018). The effect of interior design on employee's job satisfaction. Journal of Process Management: New Technologies, 6(2), 1-9. https://doi.org/10.5937/jouproman6-17462

Shkoler, O., \& Kimura, T. (2020). How does work motivation impact employees' investment at work and their job engagement? A moderated-moderation perspective through an international lens. Frontiers in Psychology, 11, 38. https:// doi.org/10.3389/fpsyg.2020.00038

Silverman, M. (2004). Non-financial recognition: The most effective of rewards? Brighton: Institute for Employment Studies.
Singh, J.K., \& Jain, M. (2013). A study of employees' job satisfaction and its impact on their performance. Journal of Indian Research, 1(4), 105-111.

Singh, R. (2016). The impact of intrinsic and extrinsic motivators on employee engagement in information organizations. Journal of Education for Library and Information Science, 57(2), 197-206. https://doi.org/10.12783/issn.2328-2967/57/2/11

Singh, S.K., \& Tiwari, V. (2011). Relationship between motivation and job satisfaction of the white collar employees: A case study. Management Insight, 7(2), 31-39.

Sirota, D., Mischkind, L.A., \& Meltzer, M.I. (2006). Work fervor: Employees are as motivated as you allow them to be. Industrial Engineer, 38(1), 45-50.

Smith, E., Joubert, P., \& Karodia, A.M. (2015). The impact of intrinsic and extrinsic rewards on employee motivation at a medical devices company in South Africa. 39-87. https://doi.org/10.12816/0019006

Snelgar, R.J., Renard, M., \& Venter, D. (2013). An empirical study of the reward preferences of South African employees. SA Journal of Human Resource Management, 11(1), a351. https://doi.org/10.4102/sajhrm.v11i1.351

Snelgar, R., Shelton, S.A., \& Giesser, A. (2017). A comparison of South African and German extrinsic and intrinsic motivation. South African Journal of Economic and Management Sciences, 20(1), 1-12. https://doi.org/10.4102/sajems.v20i1.1552

Solanki, K.R. (2013). Flextime association with job satisfaction, work productivity, motivation \& employees stress levels. Journal of Human Resource Management, 1(1), 9-14. https://doi.org/10.11648/j.jhrm.20130101.12

Spector, P.E. (1997). Job satisfaction: Application, assessment, causes, and consequences. Thousand Oaks, CA: Sage.

Stander, F.W., \& Van Zyl, L.E. (2016). See you at the match: Motivation for sport consumption and intrinsic psychological reward of premier football league
spectators in South Africa. SA Journal of Industrial Psychology, 42(1), 1-13. spectators in South Africa. SA Journal
https://doi.org/10.4102/sajip.v42i1.1312

Steger, M.F., Dik, B.J., \& Duffy, R.D. (2012). Measuring meaningful work: The work and meaning inventory (WAMI). Journal of Career Assessment, 20(3), 322-337. $\mathrm{https}$ ://doi.org/10.1177/1069072711436160

Sundström, A. (2006). Beliefs about perceived competence: A literature review (EMR Report No. 55). Department of Educational Measurement, Faculty of Social Sciences, Umeå University. Retrieved from https://www.diva-portal.org/smash/ record.jsf?pid=diva2\%3A154274\&dswid=-6015

Syptak, J.M., Marsland, D.W., \& Ulmer, D. (1999). Job satisfaction: Putting theory into practice. Family Practice Management, 6(9), 26.

Tausif, M. (2012). Influence of non-financial rewards on job satisfaction: A case study of educational sector of Pakistan. Asian Journal of Management Research, 2(2), 688-696.

Terera, S.R., \& Ngirande, H. (2014). The impact of rewards on job satisfaction and employee retention. Mediterranean Journal of Social Sciences, 5(1), 481. https:// employee retention. Mediterranean Journ
doi.org/10.5901/mjss.2014.v5n1p481

Thomas, K.W. (2009). Intrinsic motivation at work: What really drives employee engagement (2nd ed.). San Francisco: Berrett-Koehler Publishers.

Thompson, P. (2002). Total reward: Executive briefing. Chartered Institute of Personnel and Development. London: Short run Press.

Ushie, E.M., Agba, A.M.O., \& Okorie, C. (2015). Work environment and employees' commitment in agro-based industries in Cross River State, Nigeria. Global Journa of Human-Social Science Research, 15(6), 9-15.

Vallerand, R.J. (2001). A hierarchical model of intrinsic and extrinsic motivation in sport and exercise. In G.C. Roberts (Ed.), Advances in motivation in sport and exercise (pp. 263-319). Champaign, IL: Human Kinetics.

Vallerand, R.J., \& Reid, G. (1984). On the causal effects of perceived competence on intrinsic motivation: A test of cognitive evaluation theory. Journal of Sport and Exercise Psychology, 6(1), 94-102. https://doi.org/10.1123/jsp.6.1.94

Victor, J., \& Hoole, C. (2017). The influence of organisational rewards on workplace trust and work engagement. SA Journal of Human Resource Management, 15(1), 1-14. https://doi.org/10.4102/sajhrm.v15i0.853

Westover, J.H., \& Taylor, J. (2010). International differences in job satisfaction. The effects of public service motivation, rewards and work relations. Internationa Journal of Productivity and Performance Management, 59(7/8), 811-828. https:// doi.org/10.1108/17410401011089481

Wiese, M., \& Coetzee, R. (2013). The importance of non-financial motivators to pharmaceutical sales representatives: A demographic study. Southern African Business Review, 17(1), 23-56.

Willis Towers Watson. (2018). Mapping the new total rewards journey. Retrieved from Willistowerswatson.com

WorldatWork. (2007). The WorldatWork handbook of compensation, benefits and total rewards: A comprehensive guide for HR professionals. New York: John Wiley total reward

Yao, C., Parker, J., Arrowsmith, J., \& Carr, S.C. (2017). The living wage as an income range for decent work and life. Employee Relations, 39(6), 875-887. https://doi. org/10.1108/ER-03-2017-0071

Yeh, Y.P. (2014). Exploring the impacts of employee advocacy on job satisfaction and organizational commitment: Case of Taiwanese airlines. Journal of Air Transport Management, 36, 94-100. https://doi.org/10.1016/j.jairtraman.2014.01.002

Yousaf, S., Latif, M., Aslam, S., \& Saddiqui, A. (2014). Impact of financial and non-financial rewards on employee motivation. Middle-East Journal of Scientific Research, 21(10), 1776-1786. http://doi.org/10.5829/idosi.mejsr.2014.21.10.21756

Yusof, H.S.M., Munap, R., Badrillah, M.I.M., Ab Hamid, N.R., \& Khir, R.M. (2017). The relationship between organizational culture and employee motivation as moderated by work attitude. Journal of Administrative and Business Studies, 3(1), 21-25. https://doi.org/10.20474/jabs-3.1.3 